PONTIFÍCIa UNIVERSIDADE CATÓLICA do RIO dE JANEIRO

\title{
A influência de um filme na compra de produtos derivados \\ O caso da franquia Meu Malvado Favorito
}

\section{Adriana Carneiro Paulo}

Trabalho de Conclusão de Curso

Centro de CIÊnCIAS SOCIAIS - CCS

DEPARTAMENTO de AdMINISTRAÇÃo

Graduação em Administração de Empresas 


\section{Adriana Carneiro Paulo}

\section{A influência de um filme na compra de produtos derivados \\ O caso da franquia Meu Malvado Favorito}

Trabalho de Conclusão de Curso

Trabalho de Conclusão de Curso, apresentado ao programa de graduação em Administração da PUC-Rio como requisito parcial para a obtenção do titulo de graduação em Administração.

Orientadora: Alessandra Baiocchi A. Corrêa 


\section{Agradecimentos}

Aos meus pais,

Por todo amor, carinho, educação e dedicação investidos em mim. Por sempre buscarem o melhor para mim e por serem verdadeiros mestres com quem procuro aprender em todos os aspectos da vida.

Aos meus familiares,

Que sempre acreditaram no meu potencial e vibraram a cada conquista minha.

Aos meus amigos,

Sempre presentes na minha vida, me ajudando a superar cada dificuldade que surgia ao longo dessa caminhada e responsáveis por diversos momentos de felicidade que vivi até hoje.

À professora (e mestre), Alessandra Baiocchi,

Que me proporcionou muito conhecimento durante toda a graduação. Uma professora excepcional, cuja sabedoria e seu nível de exigência foram fundamentais na construção deste trabalho e na minha formação como administradora.

Aos demais,

Que de alguma maneira participaram da minha trajetória ao longo da universidade, transmitindo conhecimento e acrescentando experiências que me fizeram crescer como pessoa. 


\section{Resumo}

PAULO, Adriana. A influência de um filme na compra de produtos derivados: O caso da franquia Meu Malvado Favorito. Rio de Janeiro, 2015. Número de páginas: 50. Trabalho de Conclusão de Curso Departamento de Administração. Pontifícia Universidade Católica do Rio de Janeiro.

O presente estudo pretende investigar se a franquia de filmes do Meu Malvado Favorito influencia os consumidores na compra de produtos derivados. Para isto foram realizadas pesquisas bibliográficas e pesquisa de campo, com entrevistas a vendedores e consumidores, além da observação do processo de compra por parte da pesquisadora.

O resultado deste estudo proporcionou uma melhor compreensão do que motiva a compra destes produtos agregados e a influência que o filme, ainda que já tenha saído de cartaz, exerce sobre a compra.

\section{Palavras- chave}

Filmes de desenho animado, cinema, produtos derivados, comportamento do consumidor.

\section{Abstract}

PAULO, Adriana. The influence of a movie on the selection of a product to buy: Case of the Despicable Me franchising. Rio de Janeiro, 2015. Number of pages: 50. Conclusion course thesis - Departament of Administration. Pontifícia Universidade Católica do Rio de Janeiro.

The present study has the intention to identify if the Despicable Me movie franchising makes any influence on the selection of products to buy for the consumers. To support that, it were used some bibliographic references, and qualitative researches were performed with sellers and consumers and quantitative researches were performed with consumers, in addition to an observation of the purchasing process.

In this way, it was possible to understand what motivates the selection to purchase these aggregated products and the influence that the movie, even already out of the cinemas, does on the purchasing process.

\section{Key-Words}

Cartoon, animated movie, cinema, ties-in products, consumer behavior. 


\section{Sumário}

10 tema e o problema de estudo 1

1.1 Introdução ao tema e ao problema do estudo 1

1.2. Objetivo do estudo 3

1.3. Objetivos intermediários do estudo 3

1.4. Delimitação e foco do estudo 3

1.5 Justificativa e relevância do estudo 4

2 Revisão de literatura 5

2.1. Produto Cultural 5

2.2. Produto Agregado 6

2.3. Envolvimento do Consumidor 8

2.4. O Poder das Marcas 9

2.5. Brand Equity 12

2.5.1. Branding 14

2.6. O "Eu" 14

$\begin{array}{ll}\text { 2.7. Tomada de Decisão } & 16\end{array}$

3 Métodos e procedimentos de coleta e análise de dados do $\begin{array}{ll}\text { estudo } & 19\end{array}$

3.1. Etapa 1 - Observação 19

3.2. Etapa 2 - Entrevista com vendedores 20

3.3. Etapa 3 - Entrevista com consumidores 21

3.4. Etapa 4 - Pesquisa com consumidores 23

3.5. Formas de tratamento e análise dos dados coletados para o estudo24

4 Apresentação e analise dos resultados 25

4.1. Descrição e análise dos resultados do método de observação 25

4.2. Descrição e análise dos resultados das entrevistas com os

funcionários das lojas de brinquedos $\quad 30$

4.3. Descrição e análise dos resultados das entrevistas com consumidores 
4.4. Descrição e análise dos resultados da pesquisa com consumidores 34

4.4.1. Perfil dos consumidores: 34

4.4.2. Analise dos Resultados 35

5 Conclusões e recomendações para novos estudos $\quad 40$

5.1. Sugestões e recomendações para novos estudos 41

6 Referências Bibliográficas 42

7 Anexos 46

\section{Lista de Figuras}

Figura 1: Envolvimento do Consumidor ..................................................... 8

Figura 2: Integração da comunicação do marketing com a construção do brand

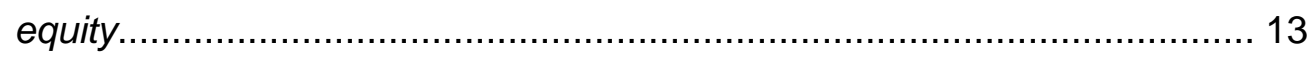

Figura 3: Etapas do processo decisório do consumidor ................................ 17

Figura 4: Boneco Minion ....................................................................... 25

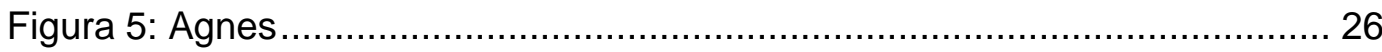

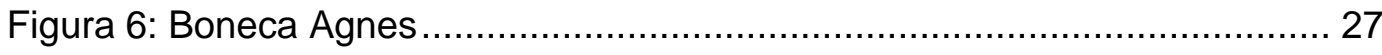

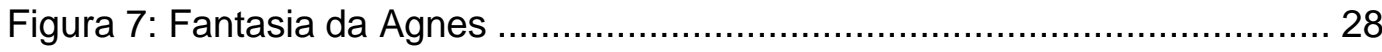

Figura 8: Boneca de pano da Agnes ...................................................... 28

Figura 9: Boneco de plástico dos Minions ................................................. 29

\section{Lista de Tabelas}

Tabela 1: Percepções da personalidade da marca........................................ 11

Tabela 2: Vantagens de marketing que uma marca forte proporciona ............... 14

Tabela 3: Níveis do Eu estendido.................................................................. 16

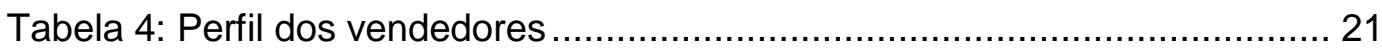




\section{Lista de Gráficos}

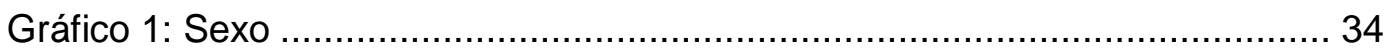

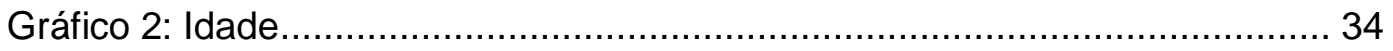

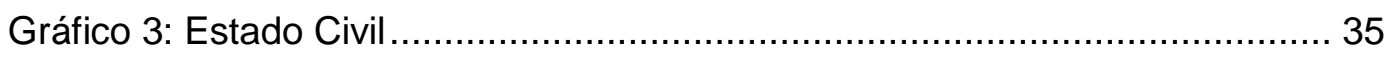

Gráfico 4: Faixa de Renda Familiar Mensal.............................................. 35

Gráfico 5: Escolaridade ....................................................................... 35

Gráfico 6: Filmes de animação que vem a cabeça ...................................... 36

Gráfico 7: Personagem mais marcante ..................................................... 37

Gráfico 8: Tipo de produtos adquiridos................................................. 38

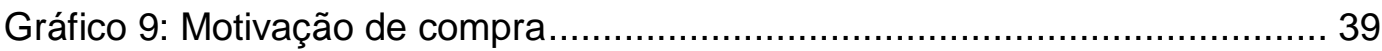




\section{0 tema e o problema de estudo}

\subsection{Introdução ao tema e ao problema do estudo}

O mercado de entretenimento abrange categorias diversas como cinema, jogos, diversão, internet, televisão, música, artes e esportes. Segundo a PWC (PWC 2013), este mercado possui uma perspectiva de crescimento a nível global de 5,7\% até 2017, movimentando assim, US $\$ 2,2$ trilhões. No Brasil, a perspectiva é de que o mercado chegue a movimentar US $\$ 71$ bilhões até 2017, pois o país vem ganhando visibilidade internacional por sediar eventos de grande porte como a Copa do Mundo em 2014 e as Olimpíadas em 2016. (SEBRAE, 2013)

Considerando o mercado global é possível perceber que os Estados Unidos da América (EUA) lideram o setor tendo uma vasta produção nas áreas do cinema e do teatro e mais de 300 variedades de parques temáticos. Os EUA são responsáveis por $25 \%$ da produção mundial do mercado cinematográfico, 93\% destes filmes são apontados como sucessos de bilheteria. (VEJA 2008)

O mercado cinematográfico atual vai além das imagens exibidas nas telas de cinema. Filmes e produtoras passaram a ser reconhecidas como marcas, atraindo uma legião de fãs que se identificam com os personagens e valores da marca. Diante disto, o poder da marca pode ser explorado buscando obter lucro através da venda de produtos relacionados (EXAME, 2015). Estes produtos temáticos, chamados de produtos agregados, derivados ou tie-in, são encontrados nas mais diversas categorias e muitas vezes continuam sendo comercializados depois que o filme já saiu de cartaz (TURNER, 1997).

Os filmes de grande sucesso de bilheteria apresentam maior oferta de produtos agregados, pois aproveitam o sucesso nas telas de cinema para oferecerem produtos que proporcionam ao consumidor uma experiência ainda mais real com o filme, gerando uma maior receita para a produtora que detém a "marca". A exploração desse segmento foi fundamental para o mercado cinematográfico visto que muitas vezes a venda de produtos agregados acaba gerando uma receita maior do que a exibição do filme em si nas telas de cinema (TURNER, 1997). 
Dentre as principais produtoras norte-americanas, encontram-se a Illumination Entretainment e sua parceira, a Universal Studios. Juntas, elas possuem um amplo portfólio de desenhos animados de longa-metragem e uma ampla variedade de produtos e serviços oferecidos ao consumidor, incluindo parques temáticos e diversos outros produtos e serviços que sempre remetem a algum personagem do filme, gerando uma relação de proximidade com o consumidor.

Neste portfólio encontra-se o filme Meu Malvado Favorito (Despicable Me) que contou com dois volumes. A história principal é sobre um anti herói que adota três irmãs órfãs e acaba se apegando a elas.

O primeiro filme estreou em 277 países, sendo lançado no Brasil em 6 de agosto de 2010 (ADORO CINEMA, 2014). Logo no fim de semana do lançamento, Meu Malvado Favorito contou com um publico de 432.063 pessoas, arrecadando um total de $\mathrm{R} \$ 5.220 .730,00$ (IBOE, 2014). O gasto para produzir o filme ficou em $R \$ 69.000 .000$ enquanto que a receita arrecada com o mesmo foi de $R \$ 543.113 .985$.

O segundo filme (Meu Malvado Favorito 2) foi lançado apenas três anos após o primeiro filme ter sido lançado, estreando nas telas dos cinemas brasileiros em 5 de julho de 2013. A estréia contou com 743.000 espectadores, e nas duas primeiras semanas de exibição arrecadou US\$ 9,7 milhões (ADORO CINEMA, 2013).

Ambos os volumes foram sucesso de bilheteria, tendo uma enorme repercussão entre pessoas das mais diferentes idades. As produtoras aproveitaram o sucesso da marca Meu Malvado Favorito e de seus personagens para oferecer uma ampla gama de produtos derivados. O filme se tornou uma marca tão poderosa que cinco anos após o lançamento do primeiro filme algumas empresas consideradas referências em seus segmentos como TicTac, Kinder, Havaianas e Chocolates Brasil Cacau compraram os direitos de licenciamento da marca para poder utilizar a imagem dos personagens do filme em seus produtos.

O sucesso dos Minions foi tão grande que estes passaram a ser considerados como marca, ganhando um filme próprio que estréia no Brasil em 25 de junho de 2015 (ADORO CINEMA, 2015). O envolvimento e a identificação das pessoas com o personagem influenciam diretamente no processo de compra dos produtos derivados do filme.

Esta influência foi percebida de maneira tão intensa que a Pantone, responsável pelo registro de cores de tinta, em parceria com o cantor Pharrell Williams, registrou uma nova cor em sua paleta: o amarelo Minion (PANTONE, 2015). 
A TicTac, marca de bala, estampou os Minions (personagens do filme Meu Malvado Favorito) não só em suas embalagens como no formato das balas. 0 TicTac Minions é uma edição limitada lançada somente nos Estados Unidos da America e conta com três Minions diferentes: Stuart, Kevin e Bob. A bala ainda possui sabor de banana, tornando a experiência do consumidor ainda mais real ao fazer referencia à adoração que os personagens possuem pela fruta nos filmes (B9, 2015).

Já a Kinder optou por uma edição especial de ovos de páscoa, que ao comprar o ovo ganhava-se um brinquedo relacionado a um personagem do filme (KINDER, 2015) e a Chocolates Brasil Cacau por uma edição de alfajor que vinha com um Minion estampado na embalagem(CHOCOLATES BRASIL CACAU, 2015).

Diante destes pontos apresentados, cabe-se a seguinte pergunta: Qual a influência que os filmes têm na compra de produtos derivados?

\subsection{Objetivo do estudo}

Este estudo tem como objetivo entender a influência que os filmes têm na compra de produtos derivados e investigar quais são os fatores que influenciam na decisão de compra de produtos derivados de personagens de filmes.

\subsection{Objetivos intermediários do estudo}

Para se atingir o objetivo final proposto esse estudo prevê, como objetivos intermediários a serem alcançados:

- Fazer uma análise do mercado de cinema.

- Estudar o mercado de produtos derivados.

\subsection{Delimitação e foco do estudo}

Este estudo será focado em entender o comportamento do consumidor de produtos agregados tendo como base os filmes do Meu Malvado Favorito 1 e 2 (Despicable Me).

Embora relevante, não se pretende com este estudo analisar o mercado de uma forma geral, mas sim concentrar a análise no mercado nacional brasileiro sob o foco de consumidores que viram os filmes e moram na cidade do Rio de Janeiro. 
As entrevistas e pesquisa do presente estudo foram realizadas no período de março a maio de 2015.

\subsection{Justificativa e relevância do estudo}

O presente estudo busca entender as diversas maneiras que um filme pode estar presente no cotidiano dos consumidores e como estes influenciam no comportamento do consumidor de produtos agregados do filme. Tal perspectiva de análise se mostra interessante por tratar de um tema com poucos estudos acadêmicos, principalmente sob a ótica do marketing, com imersão no comportamento do consumidor e no valor da marca gerado pelo filme.

As informações que este estudo pretende produzir podem ser interessantes também para empresas que atuam com entretenimento. $O$ resultado do trabalho pode apresentar subsídios para a tomada de decisão ao estudar o comportamento de seu público.

Além disso, o estudo também se faz relevante para futuras pesquisas e trabalhos acadêmicos, auxiliando em uma possível reflexão sobre o comportamento do consumidor de filmes de sucesso e seus produtos agregados. 


\section{Revisão de literatura}

Este capítulo tem como objetivo apresentar e discutir aspectos conceituais e estudos relacionados ao tema que servirão de base para análise.

Esta seção está dividida em cinco partes que abordam temas como o conceito de produto cultural e suas implicações no mercado cinematográfico, referindo-se principalmente aos produtos agregados. Serão abordados também os conceitos de envolvimento do consumidor com o produto, a fim de contextualizar a influência das marcas no cotidiano dos consumidores.

\subsection{Produto Cultural}

Segundo Colbert (2012), o marketing cultural consiste em fazer contato com os consumidores em potencial antes mesmo da aceitação do produto no mercado. Já Diggle (apud Colbert, 2012, p. 11) propõe criar uma relação entre o artista e o público, para que o máximo de consumidores possa ter contato com a obra, colocando os mesmos como foco principal de qualquer estratégia de marketing cultural, buscando também um melhor resultado financeiro.

As empresas estão cada vez mais atentas para que os consumidores percebam o que realmente está sendo oferecido como produto central e o que é uma oferta secundária. O produto central proporciona ao consumidor a satisfação de necessidades específicas, enquanto o produto secundário tem forte relação com o principal, já que oferecem benefícios adicionais ao produto principal, mas seu objetivo é melhorar a experiência de compra e diferenciá-lo da concorrência (LOVELOCK e WRIGHT, 2001). Analisando o modelo descrito por Lovelock e Wright (2001), do ponto de vista do cinema, os filmes são a oferta central, e os produtos derivados, as ofertas secundárias.

Para que a comercialização dos produtos seja feita de uma forma direcionada, as empresas devem classificar seus produtos de acordo com a quantidade de esforço que o consumidor deve desprender para comprá-lo (CHURCHILL, 2000). Segundo Kotler (2000), essa classificação ainda deve ser feita tendo em vista a grande variedade de produtos que são comercializados hoje em dia. 
Ambos os autores classificam os produtos em quatro itens, sendo eles: produtos de conveniência, produtos de compra comparada, produtos de especialidade e produtos não procurados.

Os produtos de conveniência são aqueles comprados com maior frequência e apresentam pouca fidelidade do consumidor à marca.

Os produtos de compra comparada são conhecidos também como "compra pensada", sendo aqueles que o consumidor antes de comprar faz a comparação com produtos substitutos.

A compra de produtos de especialidade envolve um produto específico, onde o consumidor está disposto a pagar um pouco mais para ter o que deseja.

Por fim, os produtos não procurados, que são aqueles que muitos consumidores não têm conhecimento da existência, onde é preciso desenvolver uma estratégia de comunicação para que os consumidores saibam de sua existência (CHURCHILL, 2000).

Apesar das quatro maneiras de distinguir os produtos, segundo Kotler (2000), Colbert (2012) afirma que na comercialização de produtos culturais são utilizadas apenas três maneiras: produtos de conveniência, produtos de compra comparada e produtos de especialidade.

Os produtos culturais geralmente se enquadram na categoria de bens de especialidade. O consumidor que deseja ver um show ou um filme específico busca comprar o ingresso com antecedência para não correr o risco de não conseguir comprar e perder o espetáculo ou filme. Em algumas situações, um produto cultural pode ser classificado como bem de compra comparada, já que o consumidor pode, por exemplo, entrar em uma livraria à procura de um determinado tipo de livro, e acabar escolhendo outro (COLBERT, 2012)

\subsection{Produto Agregado}

Neste item, busca-se entender e evidenciar como as empresas de entretenimento fazem com que seus produtos e serviços sejam desejados pelos consumidores ao agregar valor a eles, com foco em produtos agregados.

Os filmes de longa-metragem deixaram de ser um produto único para se tornarem parte de uma ampla gama de produtos e artigos culturais oferecidos aos consumidores. O desejo de assistir aos filmes está cada vez mais relacionado com outros desejos, como moda, status, novidade. Como exemplo, pode-se citar o filme "Tubarão", primeiro filme que foi sucesso de bilheteria do 
cinema de Hollywood, onde juntamente com o filme, vieram outros produtos, como trilha sonora, roupas, jogos, brinquedos, livro sobre a elaboração do filme. Desta forma, os profissionais de marketing passaram a reconhecer os filmes de longa-metragem como complexo multimídia, já que há uma expansão do filme em outros produtos e serviços (TURNER, 1997).

O mercado cinematográfico divide seus filmes em duas categorias: High concept $^{1}$ e Low concept ${ }^{2}$. Os filmes classificados como Hight concept são considerados grandes produções cinematográficas, que apresentam muitos efeitos especiais, um elenco conhecido, um roteiro que prende a atenção e encanta o telespectador. Além disso, os Hight concept possuem inúmeras formas de se lucrar com o filme, já que grande parte da receita total do filme deriva-se de produtos agregados. Nesta categoria é que se encaixam a maioria dos blockbusters. Já o conceito de Low concept está relacionado a filmes que não chamam tanto a atenção do consumidor para a aquisição de produtos. Nesta categoria encontramos filmes que são considerados verdadeiros clássicos do cinema, que também podem ter sido sucesso de bilheteria, como é o caso do filme "Cisne Negro" ou "Fantasma da Ópera", porém não apresentam uma procura grande por seus produtos derivados (NEALE e SMITH, 2013).

Os produtos derivados, geralmente, são comercializados posteriormente ou pouco tempo antes do lançamento de seu filme. Porém, existem casos de produtos que deram origem aos filmes, como é o caso da boneca Barbie e do Lego. Ambos já estavam presentes nas prateleiras das lojas quando tiveram seus filmes lançados. Neste caso, é possível considerar que o filme na verdade foi um produto agregado do brinquedo, visto que o que originou o filme foi a já existência do produto central.

De forma geral, a tendência de combinar filmes com uma variedade de produtos tem oferecido às empresas produtoras estratégias de marketing que exploraram comercialmente os produtos agregados. Estes permanecem no mercado mesmo após a passagem dos filmes em todas as mídias, gerando assim um maior valor agregado nos consumidores finais. Além disso, um produto agregado pode surgir ao reboque do sucesso de filme, sendo concebido depois que o filme saiu de cartaz, como, por exemplo, casos de bonecos, acessórios, roupas, entre outros (TURNER, 1997).

Com a globalização, houve uma maior concentração dos meios de comunicação, favorecendo o desenvolvimento do mercado cinematográfico, não apenas ao que diz respeito à bilheteria dos longas-metragens, mas também no que se refere a produtos extensivos, estejam eles fazendo referência ao filme 
como roupas, brinquedos, acessórios, ou a própria produtora, com livros ou canais de televisão. Tal expansão hoje é permitida graças à facilidade que as empresas têm em disponibilizar seus produtos ao redor do mundo (NEALE e SMITH, 2013).

\subsection{Envolvimento do Consumidor}

Segundo Peter e Olson (2010), existem três níveis de envolvimento que um consumidor pode ter com um produto, serviço ou marca: baixo, onde há pouca ou até nenhuma importância percebida; moderado, onde se percebe alguma importância; alto, quando há grande importância percebida.

O envolvimento acontece quando o produto ou serviço percebido pelo consumidor apresenta relevância, com base em suas necessidades, valores e interesses. Por se tratar de uma construção social, o envolvimento pode ser relacionado com diversos fatores, como: necessidades, interesses, valores, ocasião, compra/uso (SOLOMON, 2011). Esta relação pode ser vista ao observarmos a figura 1 abaixo:

Figura 1 - Envolvimento do Consumidor:

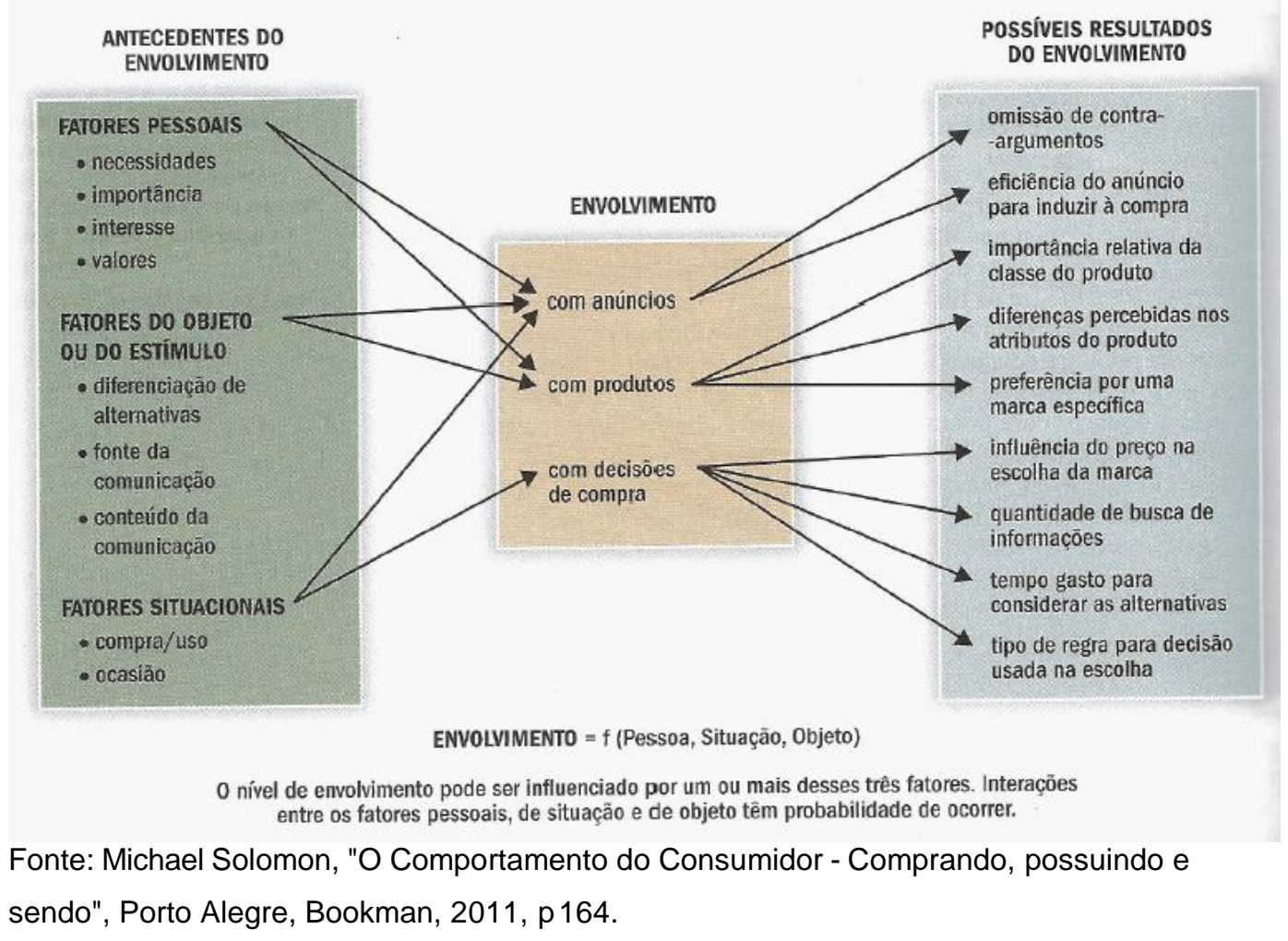


Quando o consumidor percebe a relação existente entre as necessidades e valores, sendo motivado a prestar mais atenção nas informações que os produtos ou serviços oferecem, ele também passa a ser visto como motivação a alguma ação (SOLOMON, 2011).

O envolvimento entre o consumidor e o produto/serviço motiva, estimula e direciona os procedimentos e comportamentos cognitivos e afetivos no momento da tomada de decisão. Quando se tem interesse por alguma coisa, e se está envolvido, o consumidor desprende de mais tempo para realizar a compra, uma vez que irá procurar todas as informações necessárias sobre o produto ou serviço, para satisfazê-lo (PETER e OLSON, 2010).

Considerando o envolvimento, classifica-se a tomada de decisão em três pontos: tomada de decisão rotineira, onde há baixo envolvimento, destinando-se o mínimo de tempo possível na compra do produto ou serviço; tomada de decisão limitada, onde se tem um envolvimento moderado, já que se busca informações do ambiente interno e externo, destinando pouco tempo para a compra; tomada de decisão extensiva, com alto envolvimento, considerando informações externas e investindo tempo no processo de compra (LARENTIS, 2012).

\subsection{O Poder das Marcas}

Marca pode ser definida como "um nome, termo, sinal, símbolo ou design, ou uma combinação de tudo isso, destinado a identificar os bens ou serviços de um fornecedor ou de um grupo de fornecedores para diferenciá-los dos de outros concorrentes", afirma Kotler e Keller (2012).

O conceito de marca está relacionado à reputação que a mesma adquiriu ao fazer algo desejado ou esperado pelo seu público alvo (NOBREGA, 2004). Segundo Guimarães (2003), considerando um contexto de mercados com monopólios ou oligopólios, onde não há concorrência, uma marca se resumiria apenas a um nome e uma forma gráfica, o que não corre nos dias de hoje.

A personalidade da marca é composta por características que os consumidores atribuem aos produtos, relacionando e categorizando eles (SOLOMON, 2011). Segundo Aaker (1996), a individualidade de cada produto é criada de acordo com a maneira que características humanas são relacionadas a marcas especificas, ajudando assim na formação da personalidade da marca. 
Segundo Solomon (2011), para que o consumidor construa uma relação de lealdade com a marca, é fundamental que a mesma possua uma personalidade bem sucedida e, consequentemente, produtos que se destaquem meio aos concorrentes. Desta forma, a marca será percebida como diferente das demais, tendo assim um valor diferenciado aos olhos do consumidor.

Transformar uma marca em conhecida, se tornando referencia no mercado e sinônimo de produto de qualidade é um dos grandes objetivos da maioria das empresas, que almejam ter a marca como um patrimônio da empresa (LAS CASAS, 1997).

A marca ganha valor para os consumidores de acordo com a maneira com que eles a percebem. Se o valor da marca percebido pelo cliente for grande, maior é o envolvimento do mesmo com os produtos e o esforço disposto por ele a fazer para adquirir o produto. $O$ fato de considerar a marca diferente das demais faz com que o consumidor esteja disposto a pagar mais caro pelo produto da marca do que a pagar mais barato por um mesmo produto da concorrência. A forma como a sociedade enxerga uma marca especifica é retratada pelo sentimento que os consumidores têm perante a mesma (SOLOMON, 2011).

A marca que conquista a fidelidade do consumidor sabe que ele está disposto a pagar de $20 \%$ a $25 \%$ a mais para ter um produto ou serviço associado à mesma, por acreditar que o valor desejado será atendido. A fidelidade a uma marca também torna mais difícil a entrada de concorrentes no mercado, pois independente da capacidade de fabricação destes novos concorrentes, eles enfrentarão dificuldades no que diz respeito a experiências e imagens positivas para os consumidores (KOTLER e KELLER, 2012).

$O$ forte vinculo criado entre as marcas e os consumidores fez com que os produtos e serviços passassem a ser qualificados com as mesmas características utilizadas para descrever um individuo (AAKER, 1996).

"[...] a personalidade da marca proporciona profundidade, sentimentos e apreço pelo relacionamento consumidor/marca. Esse relacionamento pode ser o alicerce para uma diferenciação real e uma vantagem competitiva." (AAKER, 1996, p.177-178). 
A marca é um fator fundamental na elaboração de uma estratégia de marketing, pois os clientes, dos mais variados segmentos, utilizam os atributos oferecidos pelas marcas para diferenciar os produtos (COLBERT, 2012).

A experiência com a marca é algo marcante para o consumidor, fazendo com que fique na memória dele se a experiência foi positiva ou negativa. Isso se reflete em decisões de compras futuras, pois uma vez que a marca possui uma imagem negativa com o consumidor ele trará esta imagem da marca para o momento presente no processo de tomada de decisão e provavelmente, não optará por esta marca (KELLER e MACHADO, 2008).

Segundo Da Paz (2011), a personalidade da marca ajuda o consumidor a diferenciá-la das demais, sendo um fator motivacional na compra de um produto, pois quando desenvolvida, torna a marca em si mais atraente, transformando-a em um objeto que retrata a personalidade do seu consumidor.

É possível definirmos uma marca através de cinco características, sendo elas: confiabilidade do nome, qualidade percebida, fidelidade e satisfação dos clientes, associação com fatores relevantes ao mercado e ativos tangíveis e intangíveis associados à marca (COLBERT, 2012).

Através da analise da personalidade da marca, consegue-se identificar os pontos fracos que a marca possui, podendo influenciar na percepção que os consumidores terão sobre a mesma. Estas percepções podem ser observadas na tabela 1.

Tabela 1 - Percepções da personalidade da marca.

\begin{tabular}{|l|l|}
\hline \multicolumn{2}{|c|}{ Ação da Marca } \\
\hline A marca é reposicionada várias vezes ou muda seu slogan repetidamente. & $\begin{array}{l}\text { Volúvel, } \\
\text { esquizofrênica }\end{array}$ \\
\hline A marca usa o mesmo personagem em seus anúncios. & Familiar, confortável \\
\hline A marca é cara e usa um sistema exclusivo de distribuição. & Esnobe, sofisticada \\
\hline A marca comfrequencia está disponível em liquidações. & Barata, sem cultura \\
\hline A marca oferece muitas extensões de linha. & Versátil, adaptável \\
\hline $\begin{array}{l}\text { A marca patrocina programas em um canal público de televisão, ou usa } \\
\text { materiais reciclados. }\end{array}$ & Útil, cooperativa \\
\hline $\begin{array}{l}\text { A marca apresenta embalagem fácil de usar ou fala no mesmo nível que o } \\
\text { consumidor em suas propagandas. }\end{array}$ & Receptiva, acessível \\
\hline A marca oferece liquidação total sazonal. & Planejada, prática \\
\hline A marca oferece garantia de cinco anos ou linha direta gratuita ao consumidor. & Confiavel, segura \\
\hline
\end{tabular}

Fonte: adaptado de Michael Solomon, "O Comportamento do Consumidor - Comprando, possuindo e sendo", Porto Alegre, Bookman, 2011, Tabela 6.2, p.249. 
Muitas marcas se associam a produtos e serviços buscando usar o seu poder para agregar valor aos mesmos e consequentemente, gerar uma receita adicional à marca. Essa associação pode ser feita através de um licenciamento de propriedade intelectual, onde o detentor da marca concede direitos a terceiros para que utilizem-na em seus produtos e serviços. Para os licenciados, esta relação é vantajosa, pois há um reconhecimento instantâneo do produto e uma valorização dos consumidores que associam o produto aos valores e conceitos já existentes ligados à marca. Para o detentor da marca, além do aumento da receita, há uma maior facilidade e agilidade na exploração de segmentos e regiões diferentes, tendo tempo hábil para focar no desenvolvimento e fortalecimento da marca (RABELO, 2007).

Esta relação ocorre muito com os personagens do filme Meu Malvado Favorito, uma vez que podemos identificá-los em diversos produtos dos mais variados seguimentos.

\subsection{Brand Equity}

O valor agregado que se identifica em um produto ou serviço é chamado de brand equity. Ele influencia na maneira de agir e de pensar dos consumidores e como os mesmos se sentem em relação à marca, podendo intervir nos preços e na lucratividade da marca (KOTLER e KELLER, 2012).

Segundo Aaker (1998), o brand equity é formado por um conjunto de fatores relacionados a todos os aspectos da marca, como símbolo, design e nome, que adicionam ou diminuem o valor que um produto ou serviço possui para os consumidores da marca. Já Guimarães (2007) refere-se ao brand equity como a capacidade da marca de alavancar capital, talentos, distribuição, consumo e parcerias no mercado a que pertence.

Segundo Kotler e Keller (2012), brand equity pode ser definido através do conhecimento da marca e da resposta que o consumidor dá em relação ao marketing dela, diferenciando-a das demais de maneira positiva ou negativa.

A figura 2 a seguir retrata a integração entre a comunicação do marketing com a construção do brand equity: 
Figura 2 - Integração da comunicação do marketing com a construção do brand equity:

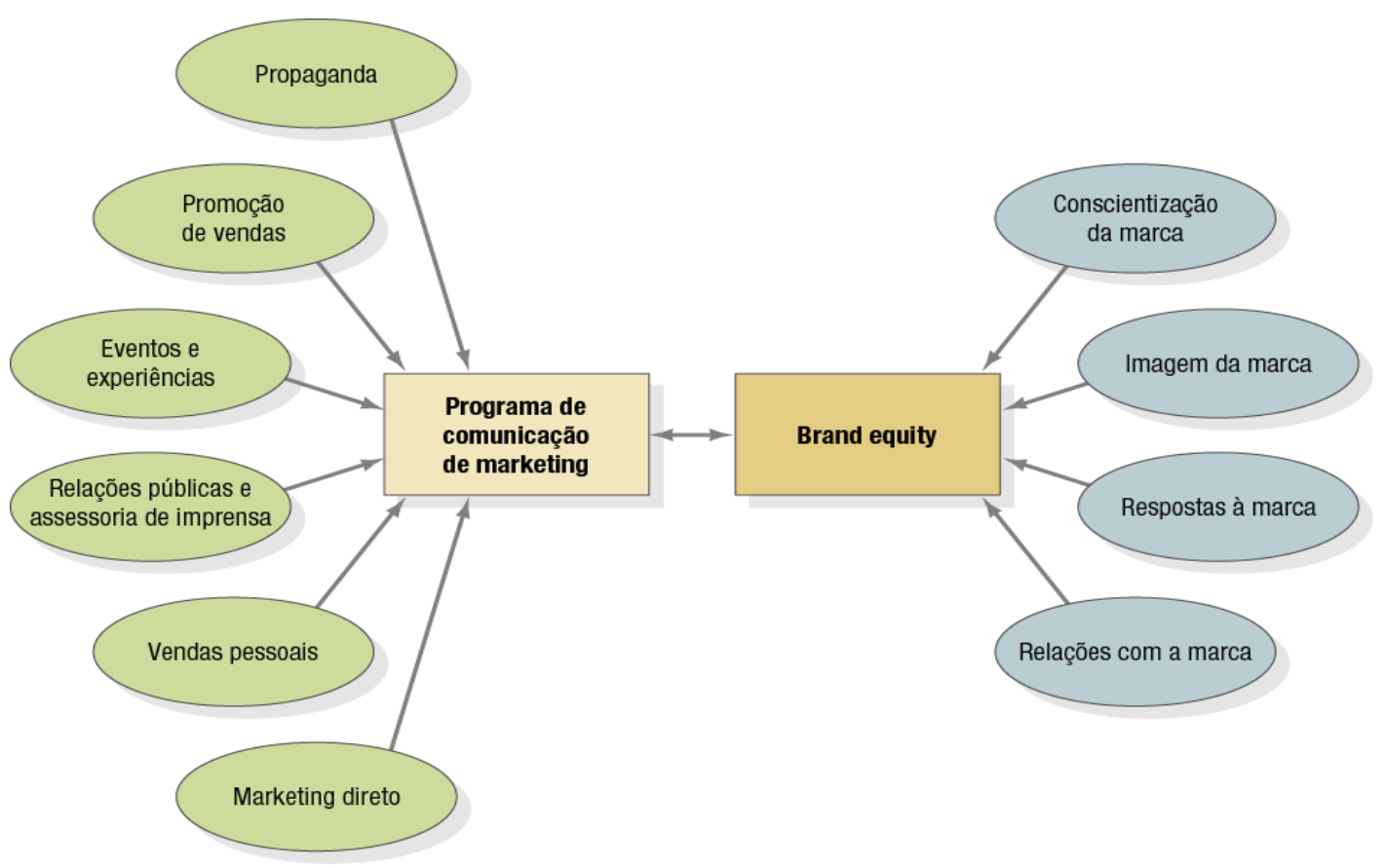

Fonte: baseado em Kotler e Keller (2012) "Administração de Marketing", material complementar Capitulo 17.

Caso o consumidor reaja de maneira positiva à marca ao identificá-la, diferentemente de quando não a identifica, pode-se dizer que a marca possui brand equity positivo. Em contra partida, uma reação negativa à marca ou uma pior reação ao ser exposto à mesma do que na ausência da mesma indicam um brand equity negativo da marca (KOTLER e KELLER, 2012).

Situações onde não há uma diferença na resposta dada pelo consumidor ao ser exposto a marca fazem com que não seja possível mensurar o brand equity da mesma. Um exemplo de produto em que isso ocorre com frequência são os commodities, pois a competição entre os concorrentes é focada nos preços ofertados.

Segundo Kotler e Keller (2012), é essencial para as marcas criarem com seus consumidores associações fortes e exclusivas, fazendo com que eles percebam na marca aspectos que sejam importantes para eles.

A tabela a seguir retrata os principais benefícios do brand equity (KOTLER e KELLER, 2012). 


\section{Tabela 2 - Vantagens de marketing que uma marca forte proporciona}

\section{Vantagens de marketing que uma marca forte proporciona}

\begin{tabular}{l|l}
\hline Melhor percepção de desempenho do produto & Maior cooperação e suporte comercial \\
Maior fidelidade & Mais eficácia das comunicações de marketing \\
Menor vulnerabilidade às ações de marketing da concorrência & Possíveis oportunidades de licenciamento \\
Menor vulnerabilidade às crises de marketing & Oportunidade adicionais de extensão da marca \\
Maiores margens & Melhor recrutamento e retenção de funcionários \\
Menos sensibilidade do consumidor aos aumentos de preço & Maiores retornos financeiros de mercado \\
Mais sensibilidade do consumidor às reduções de preço &
\end{tabular}

Fonte: adaptado de Kotler e Keller, "Administração de Marketing", São Paulo, Pearson, 2012.

\subsubsection{Branding}

Branding, segundo Kotler e Keller (2012), significa fornecer produtos e serviços com o poder de uma marca.

O maior desafio da marca é fazer com que o consumidor conheça e identifique o produto através do nome ou de aspectos da marca, entenda para quê o produto serve e se interesse por ele.

O branding busca criar diferenças entre as marcas. Para isso, é essencial que a marca seja fixada na cabeça do consumidor, pois a lembrança da marca gera valor e auxilia no processo de tomada de decisão do consumidor (KOTLER e KELLER, 2012).

O consumidor precisa identificar uma diferença significativa entre as marcas de uma mesma categoria e estas devem atender as expectativas do consumidor em relação a fatores como preço, qualidade, exclusividade, inovação, dentre outros.

\subsection{0 "Eu"}

O comportamento de um individuo está ligado à imagem que o mesmo quer passar e ser percebido pelos outros. Esses comportamentos refletem a personalidade e demais características que auxiliam no julgamento da identidade social feita sobre o outro, inclusive os comportamentos relacionados à compra de produtos.

Os produtos podem ser interpretados como um reforço da autoimagem de uma pessoa, podendo ser utilizados, por exemplo, em situações em que haja um desconforto e o individuo busque uma maior segurança (SOLOMON, 2011). 
Cada pessoa possui uma autoimagem, que está diretamente associada com a personalidade do individuo. Isso se evidencia ao percebermos que os consumidores são mais propensos a comprar produtos e serviços que correspondam e retratem esta autoimagem. (SCHIFFMAN e KANUK, 2000).

Shiffman e Kanuk (2000) acreditavam no conceito de um eu múltiplo, uma vez que os consumidores são propensos a agirem de acordo com a situação em que estão inseridos, tendo assim diferentes reações. Isto não ocorreria na ideia do eu único, pois como o próprio nome diz, seria um único eu agindo de uma mesma maneira independente da diversidade da situação em que estivesse inserido.

Se uma pessoa não possuir uma autoimagem completa, ela tenderá a completar esta autoimagem através de objetos que, ao serem adquiridos ou evidenciados, façam referencia à sua personalidade. Segundo Solomon (2011), este movimento é conhecido como teoria da autocomplementação simbólica. Há situações em que as pessoas se apegam tanto a um determinado produto que quando o perdem ou quebram, sofrem tendo a sensação de uma grande perda, e passam a ter medo de se apegar novamente a outros produtos, a fim de evitar que este sentimento de perda se repita (SOLOMON, 2011).

Devido ao valor simbólico que os produtos e marcas possuem para os consumidores, estes buscam adquirir produtos que julgam ser coerentes com a sua autoimagem e passam a evitar aqueles que não são (SCHIFFMAN e KANUK, 2000).

Schiffman e Kanuk (2000) também identificaram no consumidor cinco tipos de autoimagens: 1- real: como os consumidores se veem; 2- ideal: como os consumidores gostariam de ser vistos; 3 - social: como o consumidor sente que é visto pelos outros; 4- ideal social: como o consumidor gostaria que os outros 0 vissem; 5- esperada: como os consumidores esperam ver a si próprios em algum momento do futuro.

Há empresas que segmentam seus mercados de acordo com a autoimagem dos consumidores. Estas devem levar em conta a autoimagem esperada no momento de planejar e promover novos produtos e serviços para o consumidor, pois esta autoimagem é a que possui maior valor para o consumidor. $O$ consumidor pode mudar sua autoimagem para que ela retrate um determinado comportamento, como por exemplo, quando o consumidor busca obter prestigio social através da compra de um determinado produto (SCHIFFMAN e KANUK, 2000). 
Para Schiffman e Kanuk (2000), os consumidores buscam confirmar sua autoimagem através dos produtos que adquirem, e esta aquisição também está diretamente ligada às emoções humanas.

Segundo Solomon (2011), os produtos e acessórios usados pelas pessoas fazem parte do eu do individuo, tornando o objeto que se tem grande identificação o eu estendido da pessoa. O eu estendido pode ser dividido em quatro níveis, variando de acordo com objetos e lugares que permitam o individuo a voltar ao momento vivido, sendo elas:

\section{Tabela 3 - Níveis do Eu estendido}

\begin{tabular}{|c|c|}
\hline \multicolumn{2}{|c|}{ Níveis do Eu estendido } \\
\hline $\begin{array}{c}\text { Nível } \\
\text { Individual }\end{array}$ & $\begin{array}{c}\text { Inclusão de muitos bens pessoais na autodefinição do indivíduo. Reafirma } \\
\text { a ideia de que as coisas que uma pessoa tem, fazem parte da sua } \\
\text { identidade. Inclui jóias, carros, roupas, sapatos, etc. }\end{array}$ \\
\hline $\begin{array}{c}\text { Nível } \\
\text { Familiar }\end{array}$ & $\begin{array}{c}\text { Neste nível o aspecto central da identidade é a casa do eu. Ela passa a ser } \\
\text { vista como um corpo simbólico para a família. Inclui casa e móveis. }\end{array}$ \\
\hline $\begin{array}{c}\text { Nível } \\
\text { Comunitário }\end{array}$ & $\begin{array}{c}\text { Os consumidores fazem referência a religião ou a cidade onde nasceram. } \\
\text { Este nível é de extrema importância, para pessoas que vieram de cidades } \\
\text { pequenas e rurais. }\end{array}$ \\
\hline Nível de Grupo & $\begin{array}{c}\text { Ligações com grupos sociais também podem fazer referência ao eu. Inclui } \\
\text { símbolos, monumentos, equipamentos esportivos, etc. }\end{array}$ \\
\hline
\end{tabular}

Fonte: adaptado de Michael Solomon, "O Comportamento do Consumidor - Comprando, possuindo e sendo", Porto Alegre, Bookman, 2011, p204.

Caso em algum momento o consumidor queira melhorar sua autoimagem, isto será feito através de produtos que tenham identificação com essa autoimagem desejada e que expressem o seu novo eu (SCHIFFMAN e KANUK, 2000).

\subsection{Tomada de Decisão}

Segundo Hawkins, Mothersbaugh e Best (2007), o consumo ocorre após a identificação de um problema e o surgimento de uma oportunidade. Solomon (2011) afirma que o consumidor realiza a compra buscando solucionar um problema. 
Algumas decisões são mais importantes do que outras, fazendo com que a quantidade de esforço desempenhada nelas seja proporcional à sua magnitude (SOLOMON, 2011).

Segundo Hawkins et al. (2007), até que um produto ou serviço seja consumido o individuo obedece a cinco passos sequenciais antes da tomada de decisão: o reconhecimento do problema, a busca de informações, a avaliação e seleção de alternativas, a escolha da loja e compra e os processos de póscompra. Na figura abaixo se observa o processo de decisão do consumidor:

Figura 3: Etapas do processo decisório do consumidor

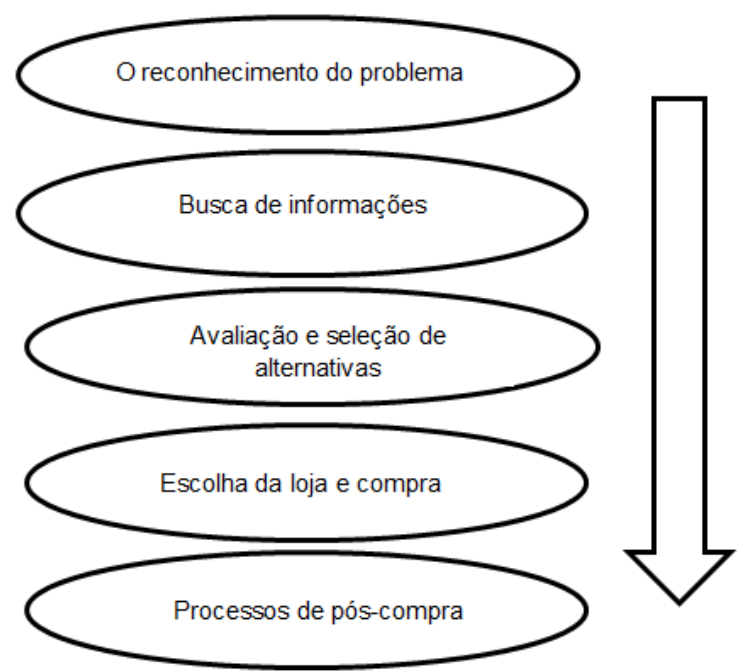

Fonte: Hawkins et al. (2007)

\section{- O reconhecimento do problema}

Esta primeira etapa do processo começa quando o individuo identifica um vazio entre o estado desejado e o estado real dele, iniciando assim o processo de decisão (SOLOMON, 2011).

Sempre que houver diferença entre a maneira como o individuo se sente (estado real) e a maneira como ele gostaria de se sentir (estado desejado), haverá o reconhecimento de um problema (HAWKINS et al., 2007).

\section{- Busca de informações}

Após a identificação do problema, o consumidor busca informações a fim de encontrar a melhor forma de solucioná-lo. É iniciada uma pesquisa, que pode ser interna, ao se tratar de lembrar as 
experiências anteriores, ou externa, onde a fonte de informação são os amigos ou meios comerciais. O consumidor pode pesquisar de mais de uma maneira, conforme julgar necessário, até obter informações suficientes sobre o que deseja (SOLOMON, 2011).

\section{- Avaliação e seleção de alternativas}

Após obter informações suficientes, os consumidores selecionam as marcas que eles vão analisar mais profundamente e os critérios que utilizarão para avaliá-las. Neste momento, percebe-se que o consumidor cria preferência por certas marcas (SCHIFFMAN e KANUK, 2009).

Segundo Solomon (2011), os critérios de avaliação adotados pelos consumidores são responsáveis pela escolha do produto.

\section{- A escolha da loja e compra}

Nesta etapa em que as alternativas já foram avaliadas pelo consumidor, ele passa a decidir a respeito das lojas e dos produtos, que tem sido uma difícil escolha mediante ao grande número de opções existentes hoje no mercado. É neste momento que a melhor alternativa é escolhida ou que encontra-se um substituto aceitável (ENGEL, BLACKWELL e MINIARD, 2000).

\section{- Processos de pós-compra}

Após a compra do produto, é feita uma avaliação pós compra para saber qual foi o resultado da compra. Neste momento, os consumidores tendem a comparar a expectativa que tinham ao comprar o produto e a experiência que tiveram após a compra. Ao analisar isto, existem três possíveis resultados: o de um sentimento neutro, quando o desempenho realizado é igual ao que se esperava; a satisfação, quando o desempenho real ultrapassa a expectativa; e a insatisfação, quando o desempenho real é inferior a aquilo que se esperava (SCHIFFMAN et al., 2009). 


\section{Métodos e procedimentos de coleta e análise de dados do estudo}

Este capítulo será dividido em cinco seções que buscam informar, respectivamente, sobre as etapas de coleta de dados do estudo que foi realizado, a forma de tratamento dos dados obtidos e as limitações encontradas.

Nas três primeiras seções, pretende-se abordar as fontes de informação selecionadas e a maneira utilizada para coletar as informações do estudo em cada etapa. Apresentará também as respectivas justificativas sobre as formas escolhidas para tratar e analisar os dados coletados. $\mathrm{Na}$ etapa seguinte, serão abordados os processos e instrumentos de coleta de dados utilizados no estudo e por fim, na ultima seção, as limitações do método encontradas.

\subsection{Etapa 1 - Observação}

Para a elaboração da primeira etapa da pesquisa foi utilizada a técnica de observação. Esse método envolve a análise dos padrões comportamentais de uma determinada amostra, colhendo informações sobre a situação de interesse. Neste caso, não há qualquer tipo de interação entre o observador e o observado. (MALHOTRA, 2005).

\footnotetext{
"[...] um observador treinado registra o comportamento exatamente quando ele ocorre. O observador não tenta controlar nem manipular o fenômeno que esta observando, mas simplesmente registra o que ocorre." (MALHOTRA, 2005, p.147).
}

A utilização da observação se fez interessante na primeira etapa, pois permite analisar o comportamento das pessoas envolvidas no processo de compra, sendo elas adultos, jovens ou crianças. A realização desse método foi fundamental para identificar os principais elementos percebidos pelos consumidores.

As informações obtidas na primeira etapa permitiram a compreensão da influência que os filmes exercem no comportamento do consumidor e, a partir disso, elaborar as perguntas utilizadas nas etapas seguintes da pesquisa. Para a seleção, foram analisados o comportamento de 10 pessoas que entraram em uma loja de brinquedos localizada no Shopping Rio Sul (Rua Lauro Sodré, 446 - 
Botafogo, RJ), à procura de qualquer produto que fizesse referencia aos filmes "Meu Malvado Favorito 1 e 2". A observação foi realizada nos dias 14 e 15 de março de 2015, com duração de 3 horas por dia. A loja foi escolhida pela pesquisadora devido à maior facilidade de acesso, sem que houvesse nenhuma implicação por parte dos vendedores da loja na realização da pesquisa.

A pesquisadora se posicionou próxima ao balcão de pagamento e não teve contato algum com os consumidores para que não houvesse qualquer tipo de influencia dos mesmos. Durante a observação utilizou-se o conhecimento adquirido até o momento para que fosse observado apenas o comportamento do consumidor. Todas as reações foram registradas em um papel, para que depois fossem analisadas.

Por se tratar da coleta de dados subjetivos e da percepção da pesquisadora, pode ter havido um viés de percepção, uma vez que a pesquisadora pode não ter notado algo relevante para a pesquisa.

\subsection{Etapa 2 - Entrevista com vendedores}

Para elaborar a segunda etapa da coleta de dados, foi realizada uma entrevista em profundidade com funcionários de lojas de brinquedos. Sobre a entrevista em profundidade, Malhotra (2005) afirma que são conversas levemente estruturadas, direcionadas para o público-alvo da pesquisa, e que buscam obter a informação desejada.

A escolha de realizar entrevistas com funcionários de lojas de brinquedos se deu ao fato deles terem contato frequente com os clientes, e desta maneira, possuirem um maior conhecimento sobre o envolvimento do consumidor no processo de compra.

As entrevistas foram realizadas no período de 24 a 27 de março de 2015 , com dois vendedores de cada loja em quatro lojas diferentes, uma localizada no Shopping Leblon (Av. Afrânio de Melo Franco, 290), duas localizadas no Botafogo Praia Shopping (Praia de Botafogo, 400) e uma localizada no Shopping Rio Sul (Rua Lauro Sodré, 446 - Botafogo, RJ). Os perfis dos vendedores entrevistados são: 


\section{Tabela 4 - Perfil dos vendedores}

\begin{tabular}{|c|c|c|}
\hline \multicolumn{3}{|c|}{ Perfil dos Vendedores } \\
\hline Vendedor & Sexo & Local \\
\hline 1 & Feminino & Shopping Rio Sul \\
\hline 2 & Feminino & Shopping Rio Sul \\
\hline 3 & Feminino & Shopping Leblon \\
\hline 4 & Masculino & Shopping Leblon \\
\hline 5 & Feminino & Botafogo Praia Shopping - loja 1 \\
\hline 6 & Feminino & Botafogo Praia Shopping - loja 1 \\
\hline 7 & Feminino & Botafogo Praia Shopping - loja 2 \\
\hline 8 & Feminino & Botafogo Praia Shopping - loja 2 \\
\hline
\end{tabular}

Fonte: informações obtidas nas entrevistas.

Para que a pesquisa fosse realizada, foram analisadas informações relevantes para a continuação do presente estudo. Para executá-las, foi elaborado um roteiro de perguntas específicas (Anexo1) para os vendedores responderem no momento da entrevista.

O viés de resposta pode ter ocorrido caso os funcionários tenham ocultado ou fornecido informações de maneira leviana para que a entrevista acabasse mais rápido, uma vez que a mesma foi feita durante o expediente dos vendedores.

\subsection{Etapa 3 - Entrevista com consumidores}

Nesta etapa de obtenção de dados, foi realizada uma pesquisa exploratória através de entrevistas em profundidade com consumidores de produtos derivados do filme Meu Malvado Favorito. As informações obtidas nesta etapa ajudaram a estruturar o questionário quantitativo e foram fundamentais para que a pergunta do trabalho fosse respondida.

O público alvo da entrevista eram moradores do Rio de Janeiro que já tivessem consumido qualquer produto ou serviço relacionado com o filme Meu Malvado Favorito, seja para dar de presente ou para si mesmo. Os entrevistados também foram selecionados de acordo com a facilidade de acesso entre eles e a pesquisadora, sendo consideradas pessoas das mais variadas idades e do sexo masculino e feminino.

O estudo considerou pessoas que já tivessem assistido a algum dos filmes e comprado algum produto do Meu Malvado Favorito, a seleção foi de jovens de 
20 a 25 anos pertencentes à classe $A$, cuja renda familiar é igual ou superior à $\mathrm{R} \$ 9.745,00$ (FGV, 2011). Segue na tabela abaixo o perfil dos entrevistados:

Tabela 5 - Perfil dos entrevistados

\begin{tabular}{|c|c|c|c|c|}
\hline \multicolumn{5}{|c|}{ Perfil dos Entrevistados } \\
\hline Entrevistado & Idade & Sexo & $\begin{array}{l}\text { Produto(s) que } \\
\text { consumiu }\end{array}$ & Para quem era? \\
\hline$A$ & 21 anos & Feminino & $\begin{array}{c}\text { Pelúcia e boneco } \\
\text { plastico }\end{array}$ & Para a entrevistada \\
\hline$B$ & 21 anos & Feminino & Camisa e caneca & Para a entrevistada \\
\hline $\mathrm{C}$ & 21 anos & Feminino & $\begin{array}{l}\text { Pelúcia, caneta e } \\
\text { lapiseira }\end{array}$ & $\begin{array}{l}\text { Caneta e lapiseira da } \\
\text { entrevistada e pelúcia } \\
\text { para dar de presente }\end{array}$ \\
\hline $\mathrm{D}$ & 24 anos & Masculino & Camisa e almofada & Para o entrevistado \\
\hline$E$ & 57 anos & Feminino & Itens de cozinha & Para a entrevistada \\
\hline $\mathrm{F}$ & 22 anos & Masculino & Boneco plástico & Para dar de presente \\
\hline$G$ & 32 anos & Masculino & $\begin{array}{c}\text { Adesivo de parede e } \\
\text { chinelo }\end{array}$ & Para dar de presente \\
\hline $\mathrm{H}$ & 27 anos & Feminino & $\begin{array}{l}\text { Pijama, comida e } \\
\text { boneco plástico }\end{array}$ & Para a entrevistada \\
\hline I & 26 anos & Feminino & $\begin{array}{c}\text { Camisa, itens de festa } \\
\text { infantil e boneco } \\
\text { plástico }\end{array}$ & $\begin{array}{c}\text { Boneco de plástico } \\
\text { para dar de presente. } \\
\text { Demais itens para a } \\
\text { entrevistada. }\end{array}$ \\
\hline
\end{tabular}

Fonte: informações retiradas dos resultados obtidos nas entrevistas com os consumidores.

As entrevistas ocorreram dos dias 10 a 14 de abril de 2015. As perguntas foram baseadas nas informações obtidas nas etapas anteriores, buscando serem perguntas especificas (Anexo 2).

Durante esta etapa, pode ter ocorrido um viés, uma vez que os entrevistados foram pessoas próximas ao pesquisador e podem ter dado respostas que auxiliassem a pesquisa. Outro viés é se o entrevistado nunca tiver assistido à nenhum dos filmes do Meu Malvado Favorito, interferindo assim na análise dos dados. 


\subsection{Etapa 4 - Pesquisa com consumidores}

Para obtenção de dados na última etapa, foi realizada uma pesquisa quantitativa com os consumidores sobre os produtos derivados do filme Meu Malvado Favorito. O objetivo desta etapa era obter informações suficientes para responder a pergunta do presente trabalho.

Segundo Kottler (1998), a pesquisa quantitativa é geralmente utilizada após uma pesquisa qualitativa, pois a etapa qualitativa gera as hipóteses e conhecimento necessário para construir um questionário quantitativo, que permite testar uma hipótese junto ao público alvo.

Nesta etapa, foi estruturado um questionário desenvolvido com base nas informações obtidas através da entrevista com os consumidores. O público alvo são pessoas residentes do Rio de Janeiro que consumam produtos e serviços relacionados ao filme Meu Malvado Favorito. O questionário foi estruturado no programa Qualtrics e distribuído e respondido de maneira virtual, considerando pessoas de idades variadas, dos sexos femininos e masculino.

A amostra contou com 150 respondentes e o perfil da amostra foi composto de $52 \%$ do sexo feminino e $48 \%$ do sexo masculino, tendo a grande maioria entre 20 e 25 anos e solteiro.

O questionário ficou disponível para ser respondido entre os dias 20 e 29 de abril de 2015. As perguntas eram especificas, tendo uma pergunta aberta e uma tabela Likert, mas sendo em sua grande maioria fechadas. (Anexo 3)

$O$ viés que pode ter ocorrido nesta etapa é dos respondentes não terem respondido ao questionário de maneira focada e acabassem dando uma resposta leviana para que o questionário acabasse logo, ou que não chegassem a finalizar o questionário por achar longo ou por não ter interesse. Outro fator relevante é um viés de resposta é devido aos respondentes serem do ciclo de convivência do pesquisador. Neste caso, o respondente que soubesse do tema da pesquisa pode ter respondido a mesma buscando ajudar a pesquisa, respondendo assim de maneira tendenciosa o questionário.

Este trabalho não representa a opinião do público em sua totalidade, visto que as opiniões e respostas a serem analisadas pertencem a uma amostra pequena se comparada ao mercado de entretenimento em geral. 


\subsection{Formas de tratamento e análise dos dados coletados para o estudo}

Nas três primeiras etapas as informações foram coletadas através dos depoimentos feitos e anotados pela pesquisadora. $\mathrm{Na}$ quarta etapa, o questionário elaborado foi distribuído e feito com o auxilio de uma ferramenta eletrônica de pesquisa, o Qualtrics, que auxiliou no tratamento dos dados obtidos.

As informações obtidas em todas as etapas foram analisadas de maneira singular, buscando-se vincular as informações colhidas de cada etapa para então identificar o envolvimento dos consumidores com o filme Meu Malvado Favorito e como esse envolvimento influencia na busca por produtos relacionados ao filme. 


\section{Apresentação e analise dos resultados}

\subsection{Descrição e análise dos resultados do método de observação}

$\mathrm{Na}$ etapa da observação, reparou-se que ao entrar em uma loja de brinquedos os pais já sabem qual produto querem comprar. A maioria do público observado era composta por mães e seus filhos que iam juntos à compra de algum brinquedo. O pai raramente acompanhava a mãe e/ou seu filho a entrarem na loja.

Quando a criança estava presente ao entrar na loja, a mesma já sabia exatamente qual brinquedo queria e a que personagem se referia, especificando bem o produto desejado. Já quando os pais entravam na loja sozinhos, sem a presença dos filhos, os mesmos não sabiam identificar o produto com tanta precisão como as crianças, sabendo apenas qual produto era e se fosse o caso, a que filme se referia. Em ambos os casos foi possível perceber o impacto do envolvimento com um personagem ou com um filme causam no consumidor.

$\mathrm{O}$ boneco mais procurado relacionado a um personagem do filme Meu Malvado Favorito foi dos Minions (Figura 4) e foi interessante perceber que todos que buscavam o personagem sabiam seu nome, sem necessidade de referenciá-lo ao filme.

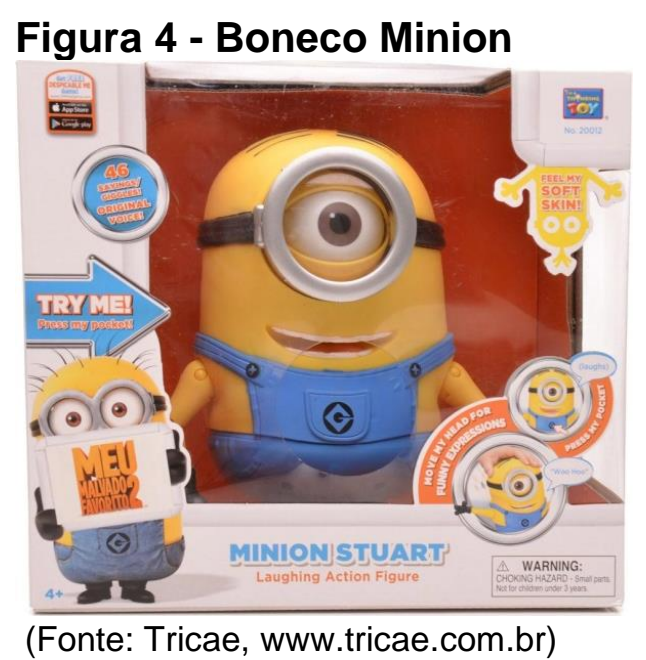


O consumidor que buscava por produtos específicos possuía um grande envolvimento com o filme, uma vez que sabia exatamente o nome do personagem que estavam buscando e, provavelmente, na ausência do produto com aquele personagem na loja dificilmente aceitaria um produto similar. Confirma-se assim a afirmação de Peter e Oslon (2010) de que o envolvimento entre o consumidor e a marca interfere de maneira a motivar, estimular e direcionar o comportamento que o consumidor terá no processo de tomada de decisão da compra.

Em um determinado momento uma criança entrou com a mãe na loja e começou a descrever detalhadamente o produto desejado, que no caso, era uma boneca da Agnes (Figura 5 - personagem do filme Meu Malvado Favorito). A criança descreveu as características físicas e roupas da personagem e chegou até a imitar uma ação da personagem no filme. O vendedor respondeu que não tinha a boneca na loja e ofereceu uma outra, mostrando para a criança a que ele tinha e buscando realizar a venda. A menina não aceitou e ficou repetindo que tinha que ser a Agnes (Figura 6) e que não queria outra. Como desfecho, a mãe agradeceu ao vendedor e disse à menina que a levaria em outra loja para ver se achavam a boneca desejada.

\section{Figura 5 - Agnes}

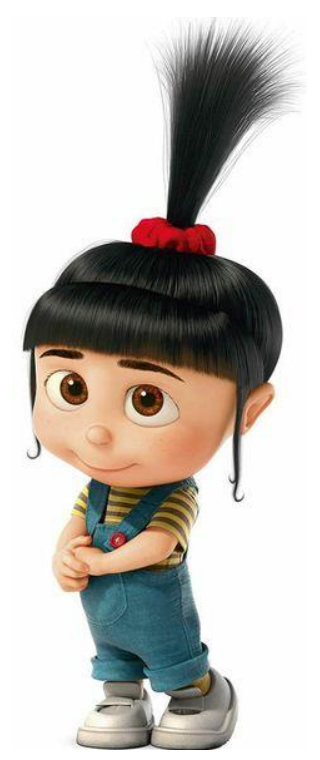

(Fonte: www.pinterest.com) 


\section{Figura 6 - Boneca Agnes}

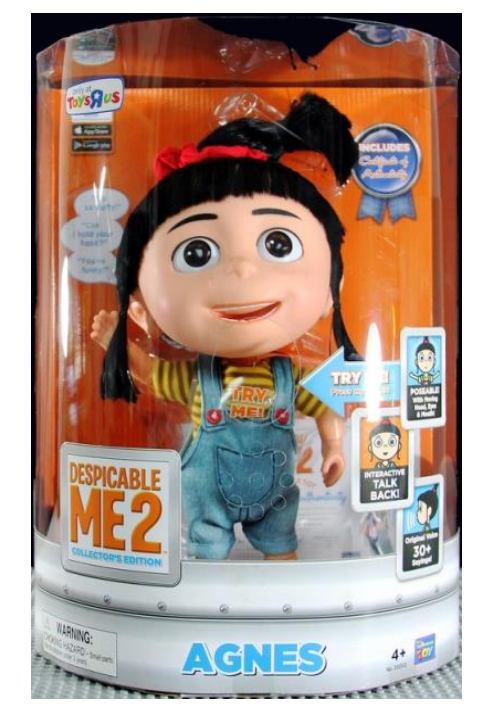

(Fonte: Amazon, www.amazon.com)

Essa situação retrata mais uma vez o processo de escolha e de tomada de decisão do consumidor antes de chegar ao ponto de venda, e como ele tem relação com o envolvimento do mesmo com a marca. Segundo Solomon (2011), o envolvimento ocorre no momento em que o produto apresenta relevância quando comparado com o interesse do consumidor, fazendo assim com que este dê maior valor às características do produto, não aceitando substitutos.

Em ambas as situações, não houve qualquer restrição dos pais em relação ao produto escolhido pelos filhos. A única interferência que houve foi no momento que o brinquedo desejado não se encontrava na loja, pois neste caso os pais interferiam buscando uma solução para satisfazer o desejo do filho(a).

Houve um momento em que uma mãe entrou na loja buscando uma fantasia da Agnes (Figura 7). Ela disse à vendedora que faria a festa de 6 anos da sua filha e que a menina pediu que o tema da festa fosse o filme Meu Malvado Favorito, por isso queria dar de presente a fantasia para a filha usar na festa. A vendedora percebeu uma oportunidade e ofereceu à mãe demais produtos relacionados ao filme, que poderiam ser utilizados para decorar o ambiente da festa ou para presentear a aniversariante. A cliente acabou comprando não só a fantasia como também uma boneca de pano da Agnes 
(Figura 8), bonecos de plástico dos Minions (Figura 9) e uma mochila com os personagens do filme.

\section{Figura 7 - Fantasias da Agnes}

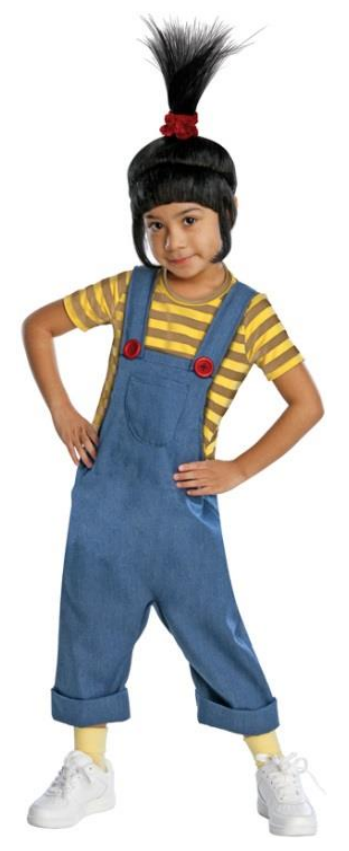

(Fonte: www.bellacollezione.com)

\section{Figura 8 - Boneca de pano da Agnes}

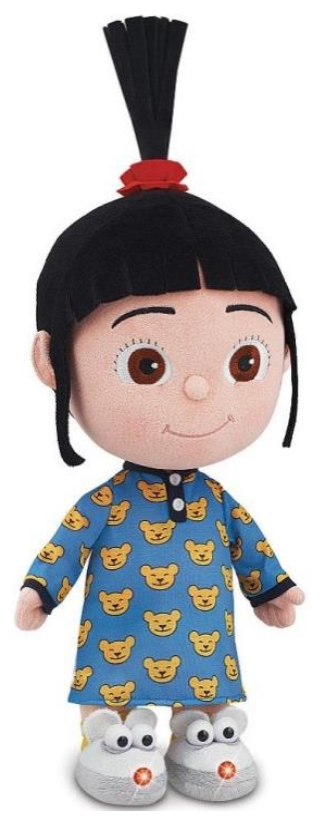

(Fonte: www.mercadodobebe.com) 


\section{Figura 9 - Boneco de plástico dos Minions}

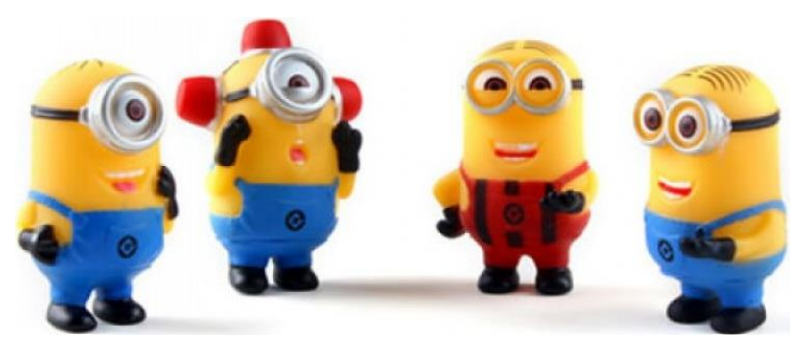

(Fonte: www.lojaroupasfemininasonline.com.br)

Neste caso foi possível perceber a relevância do envolvimento com a marca no momento da compra, pois mesmo sem a presença da filha a mãe buscava no processo de compras produtos relacionados ao filme Meu Malvado Favorito. A busca por esses produtos específicos ocorreu pela experiência que a filha teve ao ver o filme e o desejo gerado após essa experiência.

Segundo Larentis (2012), o tipo de tomada de decisão está diretamente ligado ao envolvimento do consumidor. No caso desta observação, percebe-se que a tomada de decisão é do tipo em que há um alto envolvimento do consumidor, pois há um tempo demandado na compra do produto e são consideradas no processo de compra informações externas.

Outro caso observado foi o de um jovem, que aparentava ter uns 17 anos, e entrou na loja e ficou olhando as prateleiras como se estivesse buscando por algo. Uma vendedora veio atendê-lo, perguntando se poderia ajuda em algo e ele disse que buscava por uma pelúcia de Minion, personagem do filme Meu Malvado Favorito. A vendedora checou e disse ao rapaz que no momento o produto estava esgotado e ele mesmo perguntou se havia em alguma outra loja. Ao conferir a vendedora viu que havia em estoque e solicitou a transferência do produto entre as lojas, pegando os dados do cliente e dizendo ao mesmo que 0 produto deveria chegar na loja num prazo de 3 dias.

Ao observar este movimento de compra, ficou claro mais uma vez a importância do valor que o consumidor dá a um produto ou marca, pois o consumidor preferiu aguardar por um tempo maior até obter exatamente o produto desejado do que levar alguma outra pelúcia.

O envolvimento faz com que o consumidor construa uma relação de afeto que motiva e estimula o comportamento cognitivo do mesmo. Ao ter interesse por um produto especifico, o consumidor pode vir a levar mais tempo para realizar a compra (PETER e OSLON, 2010). 


\subsection{Descrição e análise dos resultados das entrevistas com os funcionários das lojas de brinquedos}

As entrevistas foram feitas em quatro lojas de brinquedos diferentes buscando uma maior variedade de percepções sobre a procura e a venda dos produtos relacionados ao filme Meu Malvado Favorito.

O primeiro questionamento feito foi se existiam produtos relacionados ao filme Meu Malvado Favorito e a disponibilidade desses produtos. Os funcionários disseram que a procura pelos produtos era grande, principalmente depois do lançamento do filme. Em 2015, os Minions, personagens do filme Meu Malvado Favorito, ganham um filme próprio e uma das vendedoras afirmou que a expectativa para o lançamento do filme fez com que as vendas dos produtos relacionados ao tema aumentassem muito:

\begin{abstract}
"A procura aumentou bastante agora que vai estrear o filme dos Minions. Esse personagem é um dos mais procurados aqui na loja desde o lançamento do primeiro filme do Meu Malvado Favorito. Eles são divertidos e é o personagem que mais tem produto relacionado aqui na loja. Eu mesma estou curiosa pra ver o filme, adoro eles!"
\end{abstract}

\section{Vendedora 1}

Em outra loja um vendedor disse ter vendido o último boneco de um dos personagens do filme para uma criança que chegou em busca de outro personagem:

"A mais ou menos quinze minutos atrás tínhamos o último boneco relacionado ao filme, o boneco do Gru. Uma criança entrou com a mãe na loja procurando a boneca da Agnes, mas não tinha mais na loja, mostrei o único boneco que ainda tínhamos relacionado ao filme. Mesmo não sendo o que a menina desejava, ela decidiu levá-lo e ficou feliz pensando como poderia brincar com o novo boneco. Disse inclusive que ele seria o pai de suas outras bonecas."

Vendedor 2 
Desta forma nota-se como os filmes passaram a abranger uma gama de produtos que se referenciam ao mesmo, fazendo com que a marca seja lembrada pelo público por um tempo superior ao de exibição nas telas de cinema, como afirmam Turner (1997) e Neale e Smith (2013).

Segundo Neale e Smith (2013), existem fatores que influenciam o consumo de um produto após o filme ser exibido no cinema, como os efeitos especiais, personagens carismáticos e um roteiro que encante e prenda a atenção do público. Esses aspectos presentes no filme Meu Malvado Favorito tornam a experiência cinematográfica positiva para o consumidor, influenciando assim o processo de decisão de compra de um produto derivado do filme.

$\mathrm{O}$ primeiro filme da franquia Meu Malvado Favorito estreou nos cinemas brasileiros em 6 de agosto de 2010 (ADORO CINEMA, 2014) e segundo funcionários de duas lojas diferentes os produtos começaram a ser comercializados na lojas aproximadamente dois meses antes do lançamento do mesmo. Um deles mencionou que a procura pelos produtos já é grande antes mesmo do lançamento do filme, mas que se intensifica depois do lançamento do mesmo.

Solomon (2011) e Da Paz (2011) defendem a ideia de que para uma marca ser aceita pelos consumidores ela precisa criar um vinculo com o mesmo, pois o consumidor fica disposto a comprar um determinado produto independente do preço ou de conhecê-lo quando há uma relação entre a marca e ele.

Através das entrevistas, os funcionários apontaram as crianças como as que mais buscam os produtos relacionados ao filme Meu Malvado Favorito, apesar de também haver busca por parte dos jovens.

Os funcionários dizem que a venda para pais e crianças ocorrem mais frequentemente do que as venda para um jovem ou adolescente. Um deles afirma que:

"Quase de hora em hora entra uma mãe aqui com a filha procurando o boneco do Minion, da Agnes. As vezes elas vem em busca de mochilas, estojo, merendeira ou jogos do Meu Malvado Favorito. Os jovens procuram mais bonecos e pelúcias, e ainda sim, não como as crianças.".

\section{Vendedor 3}




\subsection{Descrição e análise dos resultados das entrevistas com consumidores}

Nesta etapa, foram entrevistados nove consumidores, homens e mulheres que tinham entre 20 e 60 anos. Segundo a classificação do IBGE, todos os respondentes pertencem à classe $A$, pois possuem renda familiar superior à $\mathrm{R} \$ 9.745,00$.

Ao pedir para que citassem os primeiros três filmes de animação que viessem à cabeça, seis dos nove entrevistados citaram o filme Meu Malvado Favorito. Isto demonstra uma fixação da marca e um destaque em relação aos demais filmes de animação.

Este dado demonstra a importância que tem para a marca ser bem reconhecida pelo consumidor, refletindo desta forma a percepção que a sociedade tem da mesma ao compará-la ao mercado, como afirma Solomon (2011).

Todos os entrevistados, exceto um, já haviam assistido algum dos filmes da franquia Meu Malvado Favorito. O filme não foi confundido com nenhum outro e até o entrevistado que nunca havia visto nenhum dos filmes sabia do que se tratava o filme e de seus personagens, usando o termo "bichinhos amarelos" (Minions) para fazer referencia ao filme.

Entretanto, nota-se que a produtora do filme não foi tão fixada e associada ao filme para os consumidores, pois os mesmos confundiram muitas vezes a Universal e a Illumination com outras produtoras do mercado. Desta forma, observa-se que a referencia de marca no caso do Meu Malvado Favorito é o filme em si e não suas produtoras.

Segundo Colbert (2012), as marcas se destacam para os consumidores quando possuem atributos diferentes dos da concorrência. Ele também afirma que para ter sucesso no mercado a marca deve possuir as seguintes características: confiabilidade, associação com o mercado, qualidade de produtos, satisfação do cliente e presença de ativos associados à marca. Pela entrevista foi possível identificar que o filme Meu Malvado Favorito tem destaque em todos estes cinco pontos citados por Colbert (2012).

Todos os entrevistados, sem exceção, disseram já ter comprado algum produto relacionado aos filmes da franquia Meu Malvado Favorito. Uma das consumidoras disse colecionar os personagens do filme e mencionou ter 
escolhido comprar um lanche uma vez só porque vinha com um boneco de plástico de um dos personagens do filme de brinde:

"Eu amo os Minions (personagem do filme Meu Malvado Favorito).Tudo que vejo que tem deles eu quero comprar! Uma vez eu estava fazendo intercambio no Canadá quando lançaram uma promoção de que na compra de um lanche especifico vinha um boneco caracterizado dos Minions. Eu acabava sempre optando por comprar esse lanche quando ia comer fora, porque ai aproveitava e aumentava a minha coleção.".

Entrevistada A.

Observa-se com este depoimento que algumas vezes o envolvimento do consumidor com a marca é tão grande que ele se fideliza à marca de maneira a consumir outro produto só pela relação que este tem com o filme Meu Malvado Favorito.

Outro entrevistado disse nunca ter visto qualquer filme do Meu Malvado Favorito, mas já ter consumido produtos relacionados para presentear o sobrinho. Ele ressaltou que mesmo sem ter visto o filme, sabe reconhecer os personagens do mesmo e que seu sobrinho de 9 anos especificou que queria de presente um boneco do Gru (personagem do filme Meu Malvado Favorito):

"Fui perguntar ao meu sobrinho de 9 anos o que ele queria de presente de aniversário. Ele disse que queria o boneco do Gru (personagem do Meu Malvado Favorito) que falava e se mexia. Nunca vi o filme, então perguntei a ele quem era o Gru e ele me respondeu que era o principal, O Malvado. Curiosamente, mesmo sem ter assistido aos filmes, esta informação foi suficiente para que eu soubesse a que personagem se referia."

\section{Entrevistado F.}

Com este depoimento foi possível notar a identificação e fidelidade à marca por parte do sobrinho do entrevistado, pois ele pediu um boneco especifico, chamando o personagem do filme pelo nome. 
Segundo Solomon (2011), o envolvimento do consumidor com a marca está relacionado aos valores, necessidades e interesses que o consumidor tem na vida pessoal, fazendo com que estes busquem nos serviços e produtos valores que se identifiquem.

\subsection{Descrição e análise dos resultados da pesquisa com consumidores}

O questionário da pesquisa foi estruturado com base nas informações obtidas nas entrevistas e foi distribuído e realizado através do programa virtual Qualtrics.

\subsubsection{Perfil dos consumidores:}

\section{Gráfico 1 - Sexo:}

\begin{tabular}{|c|l|l|c|}
\hline$\#$ & Resposta & $\%$ \\
\hline 1 & Masculino & $52 \%$ \\
2 & Feminino & & $48 \%$ \\
\cline { 2 - 3 } & Total & $100 \%$ \\
\hline
\end{tabular}

\section{Gráfico 2 - Idade:}

\begin{tabular}{|c|c|c|c|}
\hline$\#$ & Resposta & & $\%$ \\
\hline 1 & Até 12 anos & 1 & $1 \%$ \\
\hline 2 & De 13 a 19 anos & E & $3 \%$ \\
\hline 3 & De 20 a 25 anos & 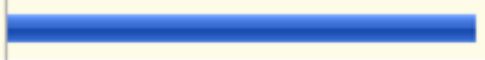 & $76 \%$ \\
\hline 4 & De 26 a 30 anos & 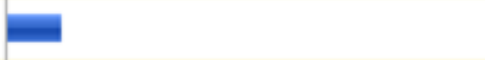 & $9 \%$ \\
\hline 5 & De 31 a 40 anos & 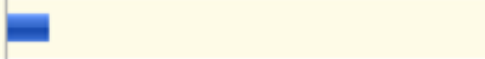 & $7 \%$ \\
\hline \multirow[t]{2}{*}{6} & Acima de 40 anos & E & $3 \%$ \\
\hline & Total & & $100 \%$ \\
\hline
\end{tabular}




\section{Gráfico 3 - Estado Civil:}

\begin{tabular}{l|l|c|}
\hline \# & Resposta & $\%$ \\
\hline 1 & Solteiro(a) & $86 \%$ \\
2 & Casado(a) & $7 \%$ \\
3 & União Estável & $5 \%$ \\
4 & Separado(a)/ Divorciado(a) I & $1 \%$ \\
5 & Viúvo(a) & $0 \%$ \\
\cline { 2 - 3 } & Total & $100 \%$ \\
\hline
\end{tabular}

\section{Gráfico 4 - Faixa de Renda Familiar Mensal:}

\begin{tabular}{|c|l|c|}
\hline \# & Resposta & $\%$ \\
\hline 1 & Até $R \$ 1.085 .00$ por mês & $4 \%$ \\
2 & De R $\$ 1.085 .00$ a R $\$ 1.734 .00$ por mês & $7 \%$ \\
4 & De R\$7.475.00 a R $\$ 9.745 .00$ por mês & $11 \%$ \\
3 & De R\$1.734.00 a R\$7.475.00 por mês & $23 \%$ \\
5 & Acima de $R \$ 9.745 .00$ por mês & $55 \%$ \\
& Total & $100 \%$ \\
\hline
\end{tabular}

\section{Gráfico 5 - Escolaridade:}

\begin{tabular}{l|l|c|}
\hline \# & Resposta & $\%$ \\
\hline 1 & Ensino Fundamental Incompleto I & $1 \%$ \\
2 & Ensino Fundamental Completo & $2 \%$ \\
3 & Ensino Médio Incompleto & $1 \%$ \\
4 & Ensino Médio Completo & $3 \%$ \\
5 & Ensino Superior Incompleto & $61 \%$ \\
6 & Ensino Superior Completo & $25 \%$ \\
7 & Pós Graduação & $7 \%$ \\
\cline { 2 - 3 } & Total & $100 \%$ \\
\hline
\end{tabular}

\subsubsection{Analise dos Resultados}

A primeira pergunta era aberta e pedia que o respondente citasse os três primeiros filmes de animação que viessem à cabeça. O Meu Malvado Favorito foi lembrado por $31 \%$ dos respondentes, só não sendo mais citado do que o concorrente Toy Story que foi citado por 37\% dos respondentes. Podemos observar abaixo uma amostra com os 15 filmes mais citados pelos respondentes: 


\section{Gráfico 6 - Filmes de animação que vem a cabeça}

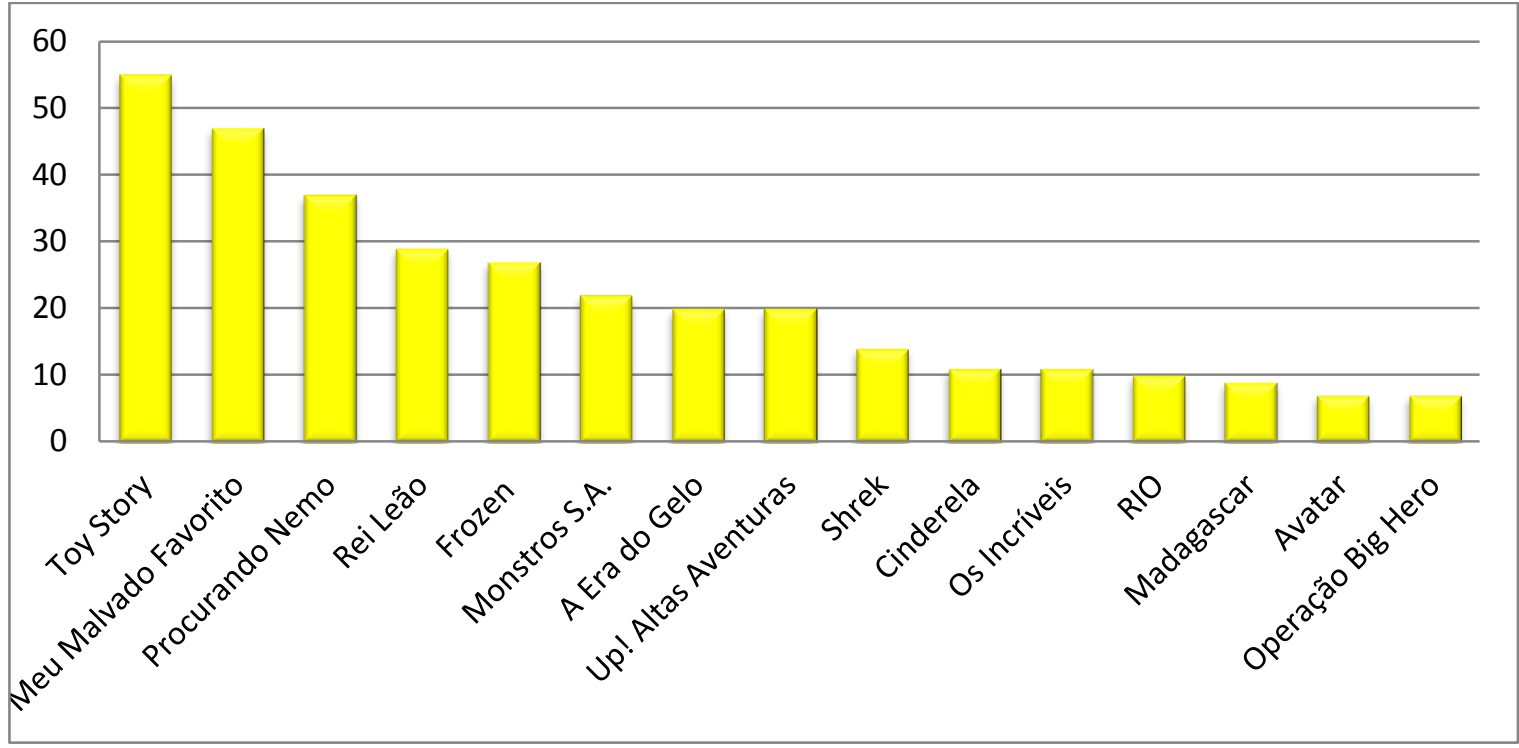

Fonte: informações retiradas dos resultados obtidos na pesquisa com os consumidores.

Isto demonstra o envolvimento do consumidor e como o filme possui uma marca forte em relação aos demais da concorrência.

Posteriormente, foi criada uma pergunta filtro, pois o estudo buscava analisar os consumidores que já houvessem assistido a algum dos filmes do Meu Malvado Favorito. As pessoas que não assistiram foram retiradas na amostra analisada.

Para os que já haviam visto o filme, foi pedido que ordenassem os personagens de acordo com o quão marcante eles eram considerados. A maioria (52\%) indicou os Minions como personagem mais marcante, seguido pelo Malvado Gru e em terceiro lugar a menina Agnes. 


\section{Gráfico 7 - Personagem mais marcante}

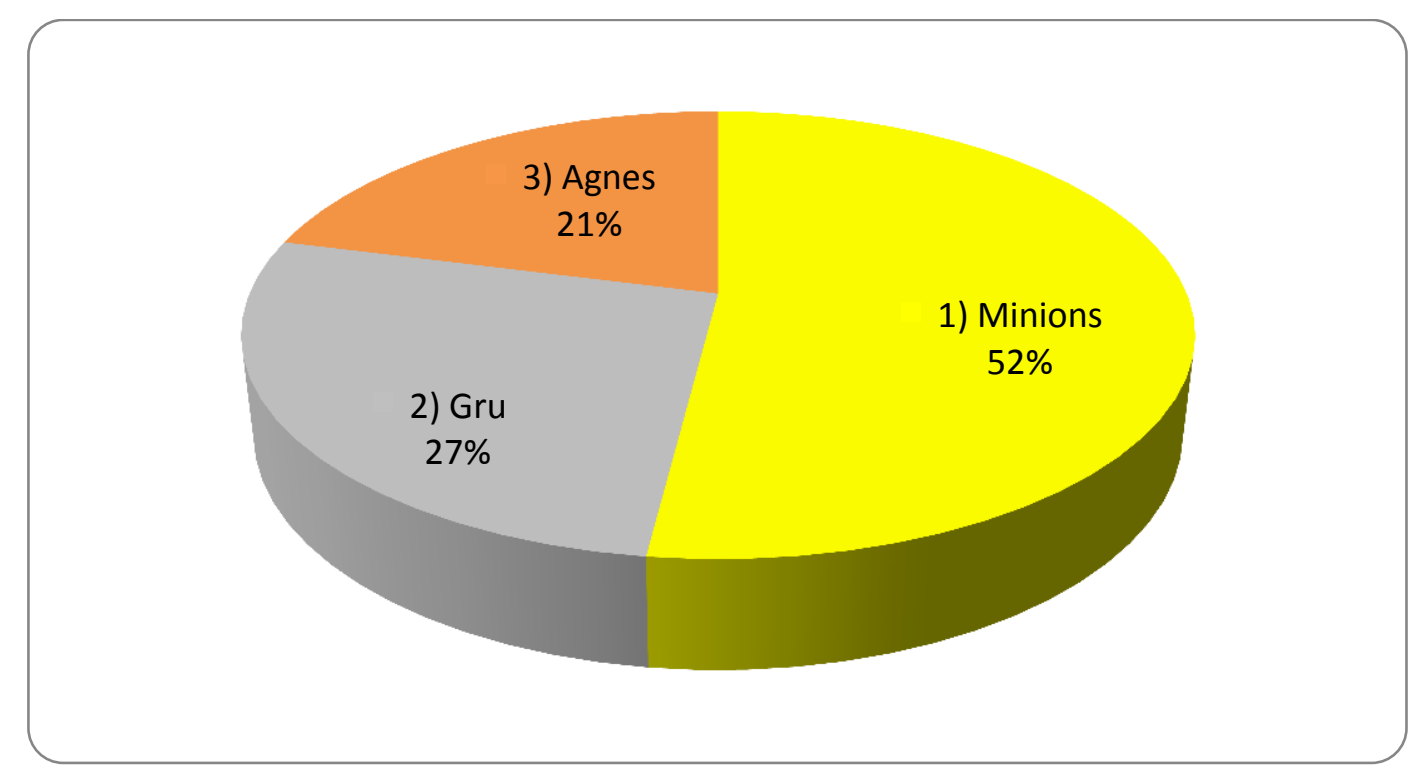

Fonte: informações retiradas dos resultados obtidos na pesquisa com os consumidores.

Segundo Solomon (2011), a maneira que a sociedade identifica uma marca está altamente relacionada com a forma como o consumidor se sente em relação à mesma. O personagem passa a ser marcante aos olhos dos espectadores de acordo com a identificação que este encontra com o mesmo.

Peter e Oslon (2010) acreditam que o envolvimento com a marca gera no consumidor uma relação de afetividade e relevância com a marca e consequentemente, com produtos e serviços relacionados à mesma.

A pesquisa identificou que $40 \%$ dos respondentes já haviam ganhado ou comprado algum produto relacionado ao universo do filme Meu Malvado Favorito. Posteriormente, foi observado que os produtos mais adquiridos pelos consumidores são pelúcias, bonecos plásticos e itens de vestuário. 


\section{Gráfico 8 - Tipo de produtos adquiridos}

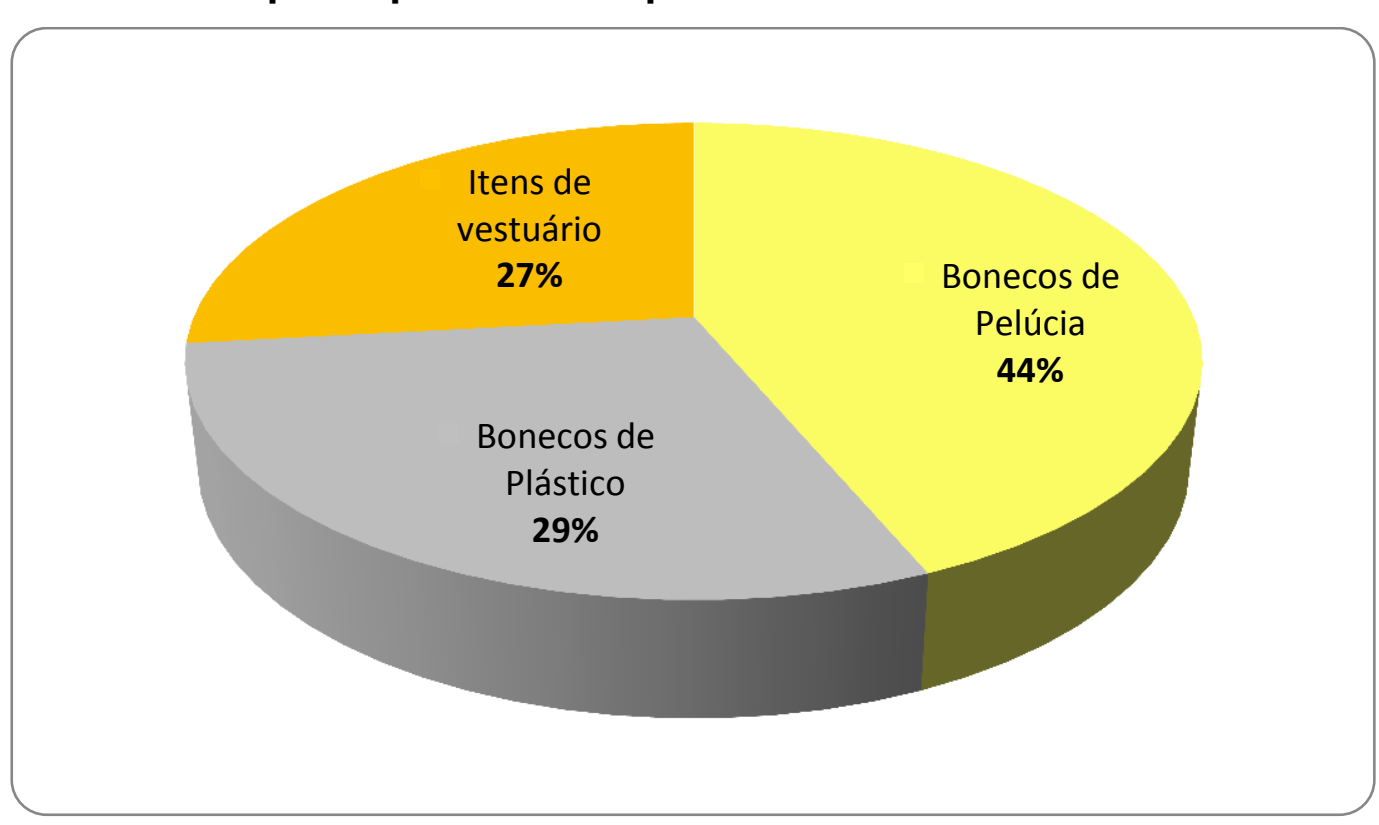

Fonte: informações retiradas dos resultados obtidos na pesquisa com os consumidores.

Neale e Smith (2013) acreditam que as grandes produtoras tendem a conciliar uma ampla gama de produtos referente a seus filmes, sejam eles lançamentos ou filmes que permanecem fazendo grande sucesso tempos após serem lançados.

O mercado de entretenimento torna os filmes permanentes na memoria dos consumidores, utilizando os produtos derivados do filme uma ferramenta para prolongar o sucesso dos mesmos ainda após o período de lançamento (TURNER, 1997).

No questionário, foi montada uma pergunta utilizando a escala Likert com o objetivo de compreender o que motivou a compra destes produtos. Os respondentes em sua maioria disseram ter consumido os produtos para presentear alguém, porém, motivos como identificação com o personagem e oportunidade também apareceram entre as motivações de compra. 


\section{Gráfico 9 - Motivação da compra}

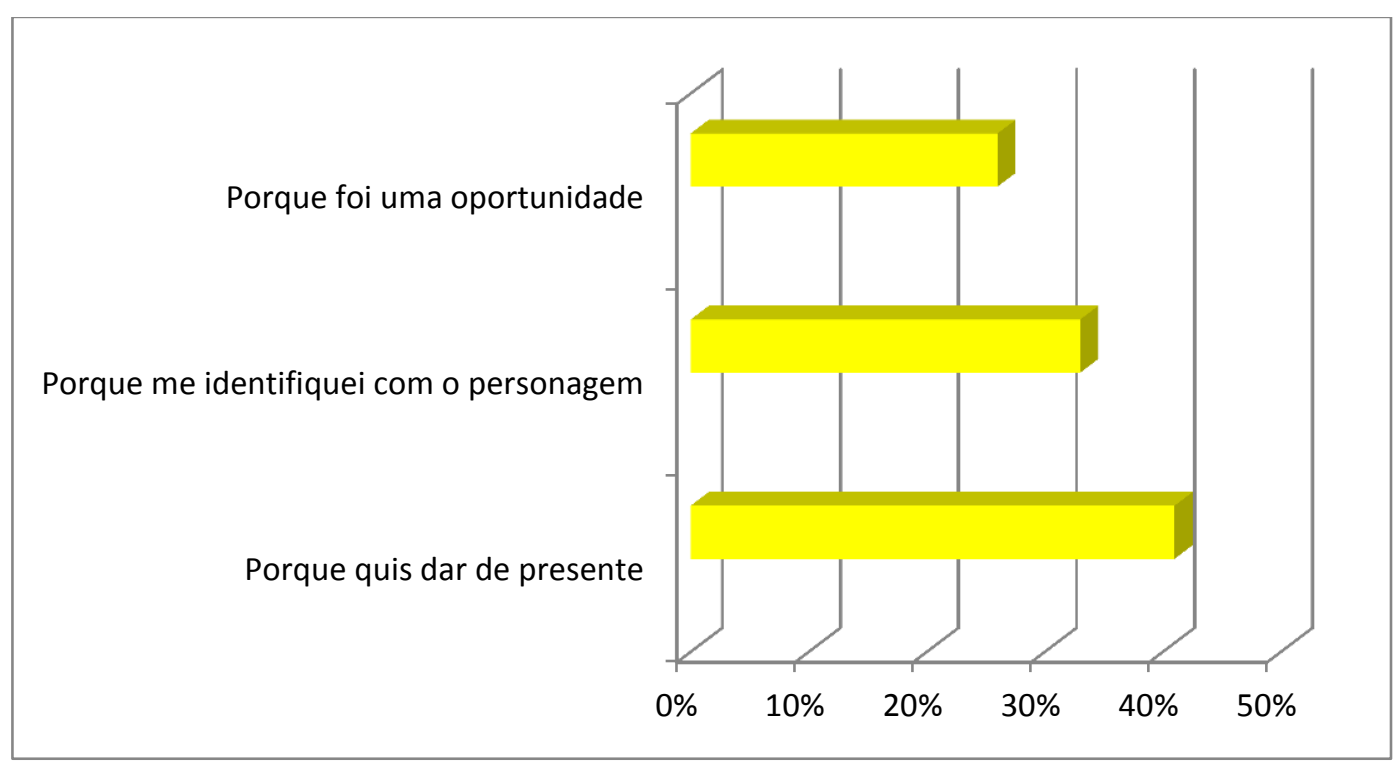

Fonte: informações retiradas dos resultados obtidos na pesquisa com os consumidores.

Segundo Da Paz (2011), a relação e o vínculo que a marca cria com o consumidor é fundamental para que haja uma preferencia no momento da compra a produtos de uma marca especifica e não aos da concorrência. Os produtos consumidos mostram que há uma grande identificação com o filme Meu Malvado Favorito, seja por parte do comprador em si ou do presenteado.

O questionário identificou o perfil dos respondentes, classificando-os por sexo, escolaridade, idade, estado civil e faixa de renda familiar. A maioria dos respondentes eram mulheres de 20 a 25 anos de idade, pertencentes à classe $A$ segundo o IBGE, solteiras e que ainda não concluíram o Ensino Superior. 


\section{Conclusões e recomendações para novos estudos}

Este capítulo resume as principais contribuições do presente trabalho ao tema estudado.

O trabalho tinha como objetivo entender a influência que os filmes têm na compra de produtos derivados e investigar quais são os fatores que influenciam na decisão de compra de produtos derivados de personagens de filmes. Considerando a ampla gama de filmes existente, o estudo focou em um filme especifico de animação: "Meu Malvado Favorito".

Os principais pontos abordados no trabalho foram: entender qual a influência que os filmes têm na compra de produtos derivados e investigar quais os fatores que influenciam na compra de produtos derivados de filmes de sucesso.

Através da pesquisa de campo, foi possível observar que o filme apresenta uma personalidade de marca muito forte, exercendo grande influência sobre a compra de produtos derivados. Os consumidores se identificam com os personagens e a maioria considera os produtos insubstituíveis. Identificou-se também que a tomada de decisão é feita muitas vezes antes que os consumidores chegassem aos pontos de venda, o que ressalta ainda mais a fidelidade à marca. Isto retrata o grande envolvimento do consumidor, principalmente conforme a ótica de Solomon (2011) e Peter e Oslon (2010).

Verificou-se que o sucesso da marca é fundamental para que haja uma fidelidade dos consumidores e para despertar sua atenção nos lançamentos futuros da marca. Nota-se que o envolvimento do consumidor e uma marca bem estabelecida são importantes para o sucesso de um filme e de seus produtos agregados.

As teorias de Turner (1997) e Neale e Smith (2013) em relação à importância da criação e da comercialização de produtos derivados pelas empresas cinematográficas para proporcionar um maior valor de marca também foram observadas na pesquisa de campo. O sucesso do filme Meu Malvado Favorito foi tão grande que este se tornou forte como marca, tendo uma ampla gama de produtos e serviços pertencentes a diversas categorias sendo comercializadas e licenciadas. 
A disponibilidade desses produtos é tão grande que, mesmo anos após os filmes Meu Malvado Favorito 1 e 2 terem saído de cartaz, ainda são comercializados novos produtos referentes ao filme, o que causa a sensação de que o produto é sempre atual, estimulando sua compra.

O estudo também revelou a relação do eu estendido com a decisão de compra de produtos derivados, pois grande parte da amostra disse ter adquirido o produto por se identificar com os personagens referenciados no mesmo.

Desta forma, considerando que os filmes de desenho animado são a oferta principal dos produtos culturais e que os produtos derivados são a oferta secundária, a pesquisa realizada indica que os produtos derivados podem ser tão ou mais importantes financeiramente para a empresa do que sua oferta principal. Entretanto, a pesquisa também aponta que a oferta principal - o produto cultural - é fundamental para criar uma marca mais poderosa e através disso, fazer com que haja uma identificação entre a marca e o consumidor.

\subsection{Sugestões e recomendações para novos estudos}

Sugere-se futuramente realizar um estudo similar a este, porém considerando outros filmes de animação.

Seria interessante se houvesse uma comparação entre a venda de produtos derivados de filmes que já existem no mercado há mais tempo com o Meu Malvado Favorito, que ainda está no auge, buscando observar o envolvimento de consumidores brasileiros com filmes já existentes no mercado.

Esta linha de estudo pode ser desenvolvida a fim de entender a influência dos filmes de desenho animado no comportamento do consumidor de produtos e serviços. 


\section{Referências Bibliográficas}

AAKER, David A. Criando e administrando marcas de sucesso. São Paulo: Futura, 1996.

AAKER, David A. Marcas: Brand Equity gerenciando o valor da marca. São Paulo: Negócio Editora, $2^{\underline{a}}$ ed. 1998.

ADORO CINEMA, 2013. Meu Malvado Favorito 2. Disponível em: < http://www.adorocinema.com/noticias/filmes/noticia-103502/>. Acesso em: 27 de maio de 2015.

ADORO CINEMA, 2014. Meu Malvado Favorito. Disponível em: < http://www.adorocinema.com/filmes/filme-140623/>. Acesso em: 27 de maio de 2015.

ADORO CINEMA, 2015. Minions. Disponível em: < http://www.adorocinema.com/filmes/filme-210493/>. Acesso em: 27 de maio de 2015.

B9, 2015. Tic Tac dos Minions - amarelos, com rostinhos e sabor de banana(!). Disponível em: <http://www.b9.com.br/57789/advertising/tictac-dos-minions-amarelos-com-rostinhos-e-sabor-de-banana/>. Acesso em: 19 de maio de 2015.

CHOCOLATES BRASIL CACAU.com, 2015. Alfajor Minions. Disponível em: < http://www.chocolatesbrasilcacau.com.br/produto/alfajor-minions/>. Acesso em: 27 de maio de 2015.

CHURCHILL, G. A. J.; PETER, J. P. Marketing: criando valor para os clientes. São Paulo: Saraiva, 2000.

COLBERT, F. Marketing for the Culture anda the Arts. Montreal: HEC, 2012.

DA PAZ, D. Personalidade da Marca: uma forma de fidelizar o cliente. Administradores, São Paulo, 14 out. 2011. Disponível em: <http://www.administradores.com.br/artigos/marketing/personalidade-da- 
marca- uma-forma-de-fidelizar-o-cliente/58868/>. Acesso em: 15 de abril de 2015.

ENGEL, JAMES F.; BLACKWELL, ROGER D.; MINIARD, PAUL W. Comportamento do consumidor. 8. ed. Rio de Janeiro: Livros Técnicos e Científicos Editora S.A., 2000.

EXAME.com. Heróis da Marvel viram marcas valiosas nas mãos da Disney. São Paulo, 2015. Disponível em: <http://exame.abril.com.br/revista-exame/edicoes/1090/noticias/herois-damarvel-viram-marcas-valiosas-nas-maos-da-disney>. Acesso em: 27 de maio de 2015.

FGV, Instituto; CPS. Qual a faixa de renda familiar das classes? 2011. Disponível em: < http://cps.fgv.br/node/3999>. Acesso em: 15 de abril de 2015.

GUIMARÃES, Ricardo. Qual é a sua definição de marca? Valor Econômico, 2003. Disponível em: < http://www.guimaraes.com.br/artigo.asp?idNoticias=226>. Acesso em: 3 de maio de 2015.

GUIMARÃES, Ricardo. Branding e Valor de Marca. 2007. Disponível em: $<$ http://www.guimaraes.com.br/artigo.asp?idNoticias=271>. Acesso em: 18 de maio de 2015.

HAWKINS, DEL I., MOTHERSBAUGH, DAVID L., BEST, ROGER J. Comportamento do consumidor: Construindo a Estratégia de Marketing. 10. ed. Rio de Janeiro: Elsevier Editora Ltda, 2007.

IBOE, 2014. Box Office Hit - Despicable Me (Bilheteria Meu Malvado Favorito). Disponível em: < http://www.iboe.com/film/box-office-hitdespicable-me>. Acesso restrito em: 14 de abril de 2015.

KELLER, K. L.; MACHADO, M. Gestão Estratégica de Marcas. São Paulo: Pearson Prentice Hall, 2008.

KINDER.com, 2015. Os personagens preferidos das crianças também estão nos ovos de Páscoa Kinder®. Disponível em: < http://www.kinder.com.br/pt_PT/kinder-ovo-

minions?formatoData $=\% 24$ dataFormat.data\&birthdayDate $=\& d=05 \& \mathrm{~m}=05 \&$ $\mathrm{y}=1992 \&$ parent $=0>$. Acesso em: 27 de maio de 2015. 
KOTLER, P; KELLER, K.L. Definição da estratégia de produto. Administração de marketing. São Paulo: Pearson/Prentice Hall, 2000.

LARENTIS, F. Comportamento do Consumidor. Curitiba: IESDE BRASIL AS, 2012.

LAS CASAS, Alexandre L; Marketing, conceitos, exercícios e casos. $4^{\text {a }}$ ed. São Paulo: Atlas, 1997.

LOVELOCK, C; WRIGHT, L. O serviço do ponto de vista do cliente. Serviços: marketing e gestão. São Paulo: Saraiva, 2001.

MALHOTRA, Naresh K. Introdução à Pesquisa de marketing. São Paulo: Prentice Hall, 2005.

NEALE, S; SMITH, M. Contemporary Hollywood Cinema. New York: Routledge, 2013.

NÓBREGA, Clemente. A Ciência da Gestão: marketing, inovação, estratégia. Rio de Janeiro: $2^{\underline{a}}$ ed. 2004.

PANTONE, 2015. Pantone Color Institute Announces PANTONE Minion Yellow (Instituto Pantone Anuncia Amarelo Minion). Disponível em: < https://www.pantone.com/pci/minion-yellow>. Acesso em: 19 de maio de 2015.

PETER, J.; OLSON, J. Comportamento do Consumidor e Estratégias de Marketing. São Paulo: McGraw Hill Brasil, 2010.

PWC. Mercado de entretenimento e mídia brasileiro chegará a US\$ 71 bilhões em 2017, segundo projeção da PwC. São Paulo, 2013 Disponível em:< http://www.pwc.com.br/pt/sala-de-imprensa/assets/pressrelease/release-14th-global-entertainment-media-outlook-2013-2017-0613.pdf>. Acesso em: 17 de abril 2015.

RABELO, Arnaldo. Licenciamento e Estratégia de Marcas. Licensing Brasil $\mathrm{n}^{\circ}$ 7, nov/dez 2007. Disponível em: < http://www.administradores.com.br/artigos/marketing/licenciamento-eestrategia-de-marcas/20431/>. Acesso em: 27 de maio de 2015.

SCHIFFMAN, L. G.; KANUK, L.L. Comportamento do Consumidor. Rio de Janeiro: LTC, 2000. 
SCHIFFMAN, L. G., KANUK, L. L.. Comportamento do consumidor. 9. ed. Rio de Janeiro: Livros Técnicos e Científicos Editora Ltda, 2009.

SEBRAE. Economia Criativa - Mercado de entretenimento chegará a US\$ 71 bilhões em 2017. São Paulo, 2013. Disponível em: < http://www.sebrae2014.com.br/Sebrae2014/Alertas/Mercado-deentretenimento- chegar\%C3\%A1-a-US\$-71-bilh\%C3\%B5es-em2017\#.U3Kq9PIdVIR>. Acesso em: 17 de abril 2015.

SOLOMON, Michael R. O Comportamento do Consumidor - Comprando, possuindo e sendo. Porto Alegre: Bookman, 2011.

TURnER, G. Cinema Como Prática Social. Tradução de Mauro Silva. São Paulo: Summus, 1997.

VEJA.com. A indústria do entretenimento que cativa o mundo. São Paulo, $2008 . \quad$ Disponível em: <http://veja.abril.com.br/idade/exclusivo/conheca_pais/eua/contexto_cultur a.html>. Acesso em: 17 de abril de 2015. 


\section{Anexos}

Anexo 1 - Roteiro para entrevista com os funcionários das lojas de brinquedo.

1. Vocês tem brinquedos/produtos do filme Meu Malvado Favorito? (pergunta filtro)

a. Se 1 sim, a procura por produtos que remetem ao filme é grande?

b. Se 1 não, porque não tem?

2. A venda desses produtos começou antes do lançamento do filme? A procura era grande?

3. Conforme o lançamento dos filmes aumentou a procura por produtos que fazem referência ao tema?

4. Com que frequência produtos desta linha são procurados por clientes na loja?

5. Qual a faixa etária que mais procura por esta linha? 
Anexo 2 - Roteiro para entrevista com os consumidores.

1. Quando você pensa em filmes de desenhos animados, qual o primeiro filme que vem a sua cabeça?

2. Você assiste ou já assistiu a algum filme do Meu Malvado Favorito?

3. Se você respondeu sim na pergunta 2, qual / quais você já assistiu?

4. O que te chama mais atenção nos filmes do Meu Malvado Favorito?

5. Você já comprou algum produto que fazia referência aos personagens ou ao universo do filme Meu Malvado Favorito?

6. Para quem você comprou?

7. Que tipos de produtos eram esses?

8. O que te levou/leva a comprar esses produtos?

\section{Perfil do consumidor}

9. Sexo:

() Masculino

() Feminino

10. Quantos anos você tem?

11. Estado civil:
( ) Solteiro(a)
( ) Casado(a)
( ) Separado(a)
( ) Divorciado(a)
( )Viúvo(a)

12. Tem filhos?
() $\mathrm{Sim}$
( ) Não

13. Se afirmativo, quantos, qual sexo e idade?

14. Qual sua faixa de renda familiar?
() até 10 salários mínimos
() de 11 a 20 salários mínimos
( ) acima de 21 salários mínimos 
Anexo 3 - Questionário feito no programa Qualtrics para pesquisa com os consumidores.

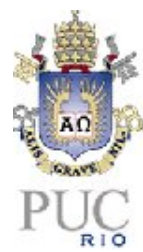

Cite os 3 primeiros filmes de animação que vêm a sua cabeça:

1)

2)

3)

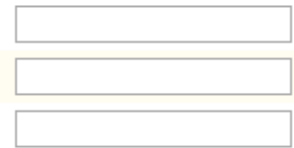

Você já assistiu algum filme do Meu Malvado Favorito?

Sim

Não

Qual/Quais você já assistiu?
- Meu Malvado Favorito 1
Meu Malvado Favorito 2
Assisti aos dois filmes

Arraste e ordene os personagens de maneira que o 1 seja o mais marcante e 5 o menos marcante:

- O Malvado Favorito - Gru

- A criança - Agnes

- Os vilões - Vector ou EI Macho

- Os Minions

- Outro. Especifique:

Você já ganhou algum produto que fazia referência aos personagens ou ao universo do filme Meu Malvado Favorito?

Sim

Não

Você já comprou algum produto que fazia referência aos personagens ou ao universo do filme Meu Malvado Favorito?
Sim

Não 


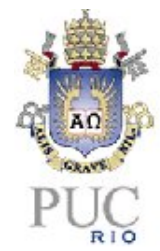

Para quem você comprou? Marque todas as necessárias.

$\square$ Comprei para dar de presente

$\square$ Comprei para mim

$\square$ Comprei o McLanche Feliz e ganhei o boneco

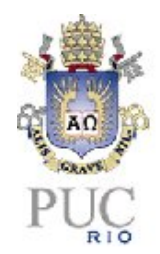

Qual a faixa etária do presenteado?

$\square$ De 0 a 7 anos

$\square$ De 8 a 12 anos

$\square$ De 13 a 19 anos

$\square$ De 20 a 30 anos

$\square$ Acima de 31 anos

Que tipos de produtos eram esses? Marque TODAS as opções necessárias, tanto para os produtos que comprou quanto para os que ganhou de presente.

$\square$ Boneco(s) de Plástico

$\square$ Boneco(s) de Pelúcia

$\square$ Itens de Papelaria

$\square$ Caixa de Som

$\square$ Acessório(s) para Celular

$\square$ Pendrive

$\square$ Fones de Ouvido

$\square$ Itens de Decoração de Festa

$\square$ Itens de Vestuário

$\square$ Roupa(s) de Banho

$\square$ Itens de Higiene Pessoal

$\square$ Alimentos com Personagens na Embalagem

$\square$ Alimentos Personalizados com Personagens

$\square$ Acessório(s) para Cama / Sofá

$\square$ Adesivo(s) 
$\square$ Utensilios de Banho
$\square$ Utensílios de Cozinha
$\square$ Mochila(s)/ Sacola(s)/Bolsa(s)
$\square$ Brinquedo(s)
$\square$ Merendeira(s)/ Sanduicheira(s)
$\square$ Bolinhas de Sabão
$\square$ Quadro(s) / Poster(s)
$\square$ Itens Decorativos
$\square$ Outro. Especifique:

\section{O que te levou a comprar este(s) produto(s)?}

Concordo

Plenamente

Concordo

Indiferente

Discordo

cordo

Porque me identifiquei com o (s) personagem(ns)

Porque foi uma oportunidade

Comprei por impulso

Porque quis dar de presente

Porque me pediram de

presente

Porque coleciono

Porque achei educativo

A funcionalidade do produto,

não pelos personagens

Porque está na moda

$\begin{array}{ll}0 & 0 \\ 0 & 0 \\ 0 & 0 \\ 0 & 0 \\ 0 & 0 \\ 0 & 0 \\ 0 & 0 \\ 0 & 0 \\ 0 & 0\end{array}$

Plenamente 
Sexo:

Masculino

Feminino

\section{Quantos anos você tem?}
Até 12 anos
De 13 a 19 anos
De 20 a 25 anos
De 26 a 30 anos
De 31 a 40 anos
Acima de 40 anos

\section{Estado Civil:}
Solteiro(a)
Casado(a)
$\bigcirc$ União Estável
O Separado(a)/ Divorciado(a)
Viúvo(a)

\section{Qual a sua faixa de renda familiar?}
Até $\mathrm{R} \$ 1.085,00$ por mês
De $\mathrm{R} \$ 1.085,00$ a $\mathrm{R} \$ 1.734,00$ por mês
De $\mathrm{R} \$ 1.734,00$ a $\mathrm{R} \$ 7.475,00$ por mês
De R $\$ 7.475,00$ a R $\$ 9.745,00$ por mês
Acima de $\mathrm{R} \$ 9.745,00$ por mês

\section{Escolaridade:}
$\bigcirc$ Ensino Fundamental Incompleto
$\bigcirc$ Ensino Fundamental Completo
Ensino Médio Incompleto
Ensino Médio Completo
Ensino Superior Incompleto
Ensino Superior Completo
Pós Graduação 